\title{
Inequality: \\ A Hidden Cost of Market Power
}

\author{
By \\ Sean F. Ennis, Pedro Gonzaga and Chris Pike*
}

Revision of 14 June, 2019

\begin{abstract}
This paper explores the impact of competition on inequality by developing a new model to illustrate how higher profits from market power, and associated higher prices, could influence the distribution of wealth and income. We analyse data from eight OECD countries - Canada, France, Germany, Korea, Japan, Spain, the United Kingdom and the United States. In an average country in the sample, market power increases the wealth of the richest $10 \%$ by between $12 \%$ and $21 \%$ for a range of reasonable assumptions about savings behaviour, while it reduces the income of the poorest $20 \%$ by $11 \%$ or more. The results contribute to the economic literature on the origins of inequality, suggesting that lack of competition may be one source of economic inequality.
\end{abstract}

JEL Classifications: D31, D42, D63

Key words: competition, inequality, market power, wealth distribution, income distribution.

\footnotetext{
* University of East Anglia, Norwich Business School (S. Ennis), OECD (P. Gonzaga and C. Pike), Corresponding author: s.ennis@uea.ac.uk. Contact for other authors: pedro.gonzaga@oecd.org, chris.pike@oecd.org. Many thanks for comments to referees, Paul Atkinson, Walter Beckert, Marco Buti, Antonio Capobianco, Simon Cowan, John Davies, Steve Davies, Jens Høj, Morten Hviid, Bruce Lyons, Joaquim Oliveira Martins, Ana Rodrigues, Ania Thiemann, Catherine Waddams, and commenters from various competition agencies and seminars or conferences at the European Commission, University of East Anglia, University College London and the World Bank. The opinions expressed and arguments employed herein are those of the authors and do not necessarily reflect the official views of the UEA, the OECD or OECD member countries.
} 


\section{Introduction}

Recent economic research finds stagnation in median wages and an increased disparity between the incomes of different groups of the population. ${ }^{1}$ Understanding the contributing factors to inequality is important if policymakers wish to reverse these tendencies. While there is much dispute about the origins of inequality, traditional explanations include a reduction in fiscal transfers from rich to poor, differences in human capital value or differences in demand for different types of workers. Increasingly, market power - defined as the ability to drive prices and returns above competitive levels - has also been identified as contributing to some extent to greater inequality. This has been noted by Ennis and Kim (2017), Furman and Orszag (2015), Rognlie (2015), Baker and Salop (2016), Creedy and Dixon (1999), as well as Comanor and Smiley (1975).

The existence of market power has a dual effect on the income distribution, not only generating higher economic profits ${ }^{2}$ for business owners, but also imposing higher prices on consumers. The wealthy, while paying more for goods, will at the same time receive higher profits from market power, due to their generally higher ownership of the stream of corporate profits and capital gains. The increased margins charged to customers as a result of market power will disproportionately harm the poor who will pay more for goods without receiving a counter-balancing share of increased profits. For example, Hausman and Sidak (2004) find evidence that poorer telecommunications consumers are more exposed to monopolisation.

The role of market power in explaining income and wealth disparities is particularly relevant in a global context where profit margins are increasing over time. Recent research, such as De Loecker and Eeckhout (2017), shows that mark-ups have increased substantially in the U.S. between 1950 and 2014, and suggests that this can be attributed to market power. Weche and Wambach (2018) find a similar evolution of mark-ups for a more recent time period in Europe, observing like De Loecker and Eeckhout (2017) a similar pattern of a drop in mark-ups during the financial crises followed by a recovery. Further evidence of rising mark-ups in the United States is documented by Gutiérrez and Phillippon (2016) and Gutiérrez (2017).

While mechanisms by which market power can affect inequality are increasingly recognised, ${ }^{3}$ the extent to which they may account for inequality is still open question. Little research has focused on the potential size of market power's impact on inequality, with the exception of a study for the United States by Comanor and Smiley (1975), subsequently updated and extended to other countries by Ennis and Kim (2017). The Comanor and Smiley (1975) model and its parameters for calibration have been 
suggested to contain substantial limits. There has been little analysis of the effects of competition on income or wealth distribution overall using alternative, more recent approaches.

Our paper helps to fill that gap by proposing a new model that addresses substantial model limitations that existed in prior work. By making a comparative static analysis between two different scenarios, one with existing levels of market power and another with competition enhanced, we model the potential impacts of market power on wealth distributions for eight OECD countries: Canada, France, Germany, Korea, Japan, Spain, the United Kingdom and the United States. The countries were selected to ensure coverage of a large share of the world's wealth, in light of data availability. The wealth distribution data comes from the OECD Wealth Database or, in the two cases where the reported data are not at the required level of detail, from commonly cited alternative sources. ${ }^{4}$

While this paper focuses on the benefits of increasing competition, it does not suggest that all sources of economic market power should be eliminated. Some degree of product market power is desirable to provide sustained incentives to innovate. Patents, trademarks and brand differentiation, for example, often involve creation of market power accompanied by a positive impact on incentive to innovate. Similarly, some degree of market power is an essential spur to investment, which is why competition laws generally do not prohibit market power as such but rather its "abuse" to restrict competition.

Some observers may suggest that illegitimate market power could not play a significant role in creating inequality. Indeed, only if market power is economically significant can it reasonably have major effects on inequality. There are reasons to consider the overall effects of illegitimate or undesirable market power as significant. Much anti-competitive behaviour by firms is hidden, because it is illegal. However, the business activities of discovered cartels already show a broad range of affected sectors. Accounting for both prosecuted and undiscovered cartels, and assuming comparable economic commerce of discovered and undiscovered cartels, Ennis (2014) suggests cartel commerce may amount to about USD 2 trillion per year, and that anti-competitive price increases from cartels are in the range of USD 200-600 billion per year.

Similarly, estimating the total rents accruing to firms protected from competition by unnecessary anticompetitive regulation is challenging. However, a study carried out by OECD (Wolfl et al., 2010) found evidence that less restrictive product market regulations may have a significant impact on growth. In particular, the study estimates that reducing barriers to entrepreneurship (such as barriers to entry and antitrust exemptions) to a level consistent with the currently observed best practices among OECD 
members would allow an average OECD country to obtain a $0.35 \%$ to $0.4 \%$ higher annual growth rate of GDP per capita.

Finally, while many modern commentators seek to distance competition law and policy from distributional concerns, it is worth noting that the origins of antitrust law lie very much in concerns about the concentration of wealth. In the United States, the antitrust laws were introduced explicitly to counter monopolisation of the economy not because of concerns about 'efficiency' but rather about undue political influence stemming from the wealth of the owners of the "trusts" (Baker and Salop, 2016).

The results of this paper can inform the debate over whether consumer surplus standards have more attractive features than total welfare standards for evaluating competition and innovation policies, as it turns out the alternatives have substantially different distributional consequences. The profits included in total welfare calculations are distributed primarily to the wealthiest segment of the population, while the consumer surplus that is in both standards is distributed more broadly. The choice over whether to prefer one standard over the other is important because it can have a direct result on regulatory policy, competition law case outcomes and policies towards innovation. ${ }^{5}$

This paper proceeds as follows: Section 2 derives and explains the model that underlies the analysis. Section 3 discusses the data used to calibrate this model. Section 4 presents the results for all the countries in the analysis. Section 5 concludes and provides directions for future work.

\section{Model}

The dynamic steady-state model that we propose captures the potential effect that higher prices would have on different groups of the population based on actual income and wealth distributions, but does not characterise all relevant phenomena related to inequality and market power. The model is steady-state in the sense that it yields income and wealth distributions that remain constant over time, in a long-run scenario where the economic growth rate and level of market power are stable. Such a model allows us to compare how income and wealth distributions would change when moving from the current level of market power to an alternate equilibrium that could exist with competitive mark-ups and thus without excess market power.

For this purpose, we make a comparative static analysis between two alternative steady states: the first is the current state where business owners have market power and which is characterised by observed distributions of wealth, income and consumption expenditures; the second is a hypothetical 
steady-state where markets are competitive and distributions of wealth, income and consumption expenditures are implied by the model and the reduction in mark-ups. We do not suggest that the economies examined are actually in steady state, but rather that the approach is a reasonable approximation to capture the essential features needed to compare long-run situations with more or less competition.

The use of our model to measure the redistributive effect of market power includes several assumptions that are worth noting. One is that market power for each country can be approximated by the difference between the average mark-up (across all sectors) in the country and a minimum mark-up that reflects the most competitive sectors across the group of studied economies. ${ }^{6}$ The method is further explained below and is designed to recognise that a significant level of mark-up is needed to cover necessary returns on investment and legitimate sources of market power such as patents and trademarks. Another is that the marginal propensity to save $\left(s^{\prime}\right)$ from increased income arising from lower prices is constant across wealth groups. This assumption simplifies the solution to the model, but does not prevent the average saving rate from varying across wealth groups. ${ }^{7}$ The assumption is a conservative one since intuition suggests and simulations confirm that accommodating a higher marginal propensity to save for the wealthier will only increase the magnitude of the redistributive effects that we identify. Another is that market power gains are distributed in proportion to the current net wealth distribution (later referred to as $f_{i}$ ). This reflects the observations that corporate income and capital gains are distributed via business ownership, so that those with the largest wealth shares (whether in the form of corporate shares, bonds, pension fund entitlements, dwellings, land or others) will, in proportion, receive the largest share of the profits. ${ }^{8}$ Finally, the price of different baskets of goods will be inflated by market power in an equal percentage. This implies that products for the poor and products for the wealthy will be equally affected by market power. To the extent that the poor are more exposed to monopolisation, the model provides conservative, lower-bound estimates.

Under these assumptions, we denote $Y$ the total income in the economy, $F$ net wealth assets, $C$ the aggregate consumption expenditure, $W$ the labour income and $R$ the capital income. All variables are nominal and we will use the superscripts $m$ and $c$ to refer to the observed values in the monopolistic and competitive steady states, respectively. In addition, we consider $g$ the economic growth rate, $\bar{s}$ the average saving rate of the economy, $s^{\prime}$ the marginal propensity to save, $\alpha_{L}$ and $\alpha_{k}$ the shares of labour and capital income in the monopolistic steady-state, and $\mu$ the mark-up, defined as the price over estimated average cost. 
As we want to isolate the redistributive effect of market power, we consider that the only impact of monopolies is to raise prices, while real output remains constant. Thus, the difference between aggregate income, consumption expenditures and wealth in the monopolistic and competitive equilibrium is driven by the price increase. Under competition, the aggregate price is equal to average cost, and the following relations hold between wealth, income and consumption with market power (denoted by $m$ ) and without (denoted by $c$ ):

$$
F^{m}=\mu F^{c}, \quad Y^{m}=\mu Y^{c}, \quad C^{m}=\mu C^{c} .
$$

The relationships established in equation (1) imply that wealth, income and consumption are higher in the monopolistic equilibrium in nominal terms, as market power increases the price level in the economy, though in real terms they are assumed to remain constant across steady states. While efficiency effects are outside the scope of the model, in reality we would also expect market power to reduce aggregate output in real terms, resulting in a deadweight loss. It is not clear though how deadweight loss affects inequality, since both business owners and consumers are harmed by lost transactions. Still, we should expect efficiency effects to impact particularly the poorest groups of the population, since the households that reduce consumption are those with lowest willingness-to-pay and that cannot afford monopoly prices.

\subsection{National income identity}

The national income identity defines aggregate output as the sum of income from labour and capital:

$$
Y^{j}=W+R^{j}, \quad \text { where } j=c, m
$$

Note that the change in price when we move to the competitive steady state does not affect labour income, which we assume remains constant across the two steady states. In fact, if market power increased prices and wages in the same proportion, the redistributive effect of market power would likely be negligible, since workers and business owners would be affected in the same way. We also do not know a priori how capital income is affected by market power, since doubling prices does not necessarily double the return on capital. However, we can use equations (1) and (2) to express $R^{c}$ in terms of $R^{m}$ (see Annex $\mathrm{A} 0$ for a complete derivation):

$$
Y^{c}=W+\underbrace{\frac{1-\mu}{\mu} W+\frac{R^{m}}{\mu}}_{R^{c}} .
$$


Focusing now on population groups, the lower case letter $i$ describes the shares of wealth $y$ and income $f$ of a particular population group. The income earned by a population group $i$ is, in each steadystate, given by equations (4) and (5), mirroring equations (2) and (3) respectively:

$$
\begin{gathered}
y_{i}^{m} Y^{m}=W_{i}+f_{i}^{m} R^{m} \\
y_{i}^{c} Y^{c}=W_{i}+f_{i}^{c}\left[\frac{1-\mu}{\mu} W+\frac{R^{m}}{\mu}\right] .
\end{gathered}
$$

In equations (4) and (5), $W_{i}$ is the labour income earned by population group $i$, whose nominal level is not affected by market power (just as for aggregate labour income in equation (2)). Subtracting equation (5) from equation (4) and using the equalities in (1) and (2) (see Annex A1 for a complete derivation), we get:

$$
y_{i}^{m}-y_{i}^{c}=(\mu-1)\left(f_{i}^{m}-y_{i}^{m}\right)+\left(1-\mu \alpha_{L}\right)\left(f_{i}^{m}-f_{i}^{c}\right) .
$$

Equation (6) states that the difference in income shares for group $i$, with and without market power, is an increasing function of the difference between the wealth share and income share of the group, and declines in the labour share (multiplied by the mark-up) times the wealth differential. This effectively suggests that a large labour share of income $\alpha_{L}$ attenuates the impact of the wealth differential on the income differential of a population group. In other words, as the labour share of income increases, those groups with a high wealth differential (i.e. particularly benefitting from market power) will have a lower income differential (i.e. a smaller jump in income due to market power).

\subsection{Consumption function}

Next, we describe aggregate consumption expenditure using a linear consumption function with an independent term (autonomous consumption) and a constant marginal propensity to save, whose functional form can be derived from a linear expenditure model: ${ }^{9}$

$$
C^{j}=\bar{C}^{j}+\left(1-s^{\prime}\right) Y^{j}, \quad j=c, m .
$$

The particular functional form of the consumption function in equation (7) implies the following relation between the marginal propensity to save $s^{\prime}$ and the average saving rate of the economy $\bar{s}$ :

$$
\bar{s}=s^{\prime}-\frac{\bar{C}}{Y}, \quad \text { where } \bar{s}=\frac{Y^{m}-C^{m}}{Y^{m}} .
$$


The relation in equation (8) reflects the fact that, as long as autonomous consumption is positive, the average saving rate is lower than the marginal propensity to save, which is line with empirical evidence. Nonetheless, this relation also imposes that the ratio of autonomous consumption to income remains sufficiently small that the average saving rate is not negative.

Defining $c_{i}$ as the consumption share of a particular population group, the consumption expenditure of any population group can be described by the following equations:

$$
\begin{gathered}
c_{i}^{c} C^{c}=\bar{C}_{i}^{c}+\left(1-s^{\prime}\right) y_{i}^{c} Y^{c} \\
c_{i}^{m} C^{m}=\bar{C}_{i}^{m}+\left(1-s^{\prime}\right) y_{i}^{m} Y^{m}, \quad \text { where } \bar{C}_{i}^{m}=\mu \bar{C}_{i}^{c} .
\end{gathered}
$$

$\bar{C}_{i}^{c}$ and $\bar{C}_{i}^{m}$ are independent terms specific to the population group. Note that despite the simplifying assumption that all population groups react identically to a variation in income, the incorporation of group-specific independent terms allows average saving rates to vary across population groups, which is consistent with empirical evidence. Still, by equation (1), the average saving rate of the economy remains the same in the monopolistic and competitive scenarios, since market power affects consumption expenditure and income in the same proportion. Multiplying equation (9) by $\mu$ and subtracting it from equation (10), it is possible to show that (see Annex A2 for a complete derivation):

$$
c_{i}^{m}-c_{i}^{c}=\frac{1-s^{\prime}}{1-\bar{s}}\left(y_{i}^{m}-y_{i}^{c}\right)
$$

Equation (11) describes how consumption shares react to a change in income share, an effect that intuitively depends on the saving behaviour characterised by the marginal propensity to save and the average saving rate, with a higher marginal propensity to save converting into a lower consumption differential for group $i$ compared to their income differential.

\subsection{Wealth dynamics}

We describe aggregate wealth in steady-state as the product of savings (aggregate income minus aggregate consumption expenditure) and a multiplier $\frac{1}{g}$, where $g$ can be interpreted as the growth rate of the economy:

$$
F^{j}=\frac{Y^{j}-C^{j}}{g}, \quad j=c, m .
$$


Equation (12) can be easily derived as the solution of a standard difference equation for wealth, by considering that in equilibrium wealth grows at the constant rate $g \cdot{ }^{10}$ In equilibrium, the same relation must be true for any particular population group:

$$
\begin{aligned}
f_{i}^{c} F^{c} & =\frac{y_{i}^{c} Y^{c}-c_{i}^{c} C^{c}}{g} \\
f_{i}^{m} F^{m} & =\frac{y_{i}^{m} Y^{m}-c_{i}^{m} C^{m}}{g} .
\end{aligned}
$$

Multiplying all terms of equation (13) by $\mu$ and subtracting it from equation (14), one can show that (see Annex A3 for a complete derivation):

$$
f_{i}^{m}-f_{i}^{c}=\frac{1}{\bar{s}}\left(y_{i}^{m}-y_{i}^{c}\right)-\frac{1-\bar{s}}{\bar{s}}\left(c_{i}^{m}-c_{i}^{c}\right) .
$$

It must be noted that in the special case where $g$ takes the value zero, equation (12) does not hold and wealth is instead constant over time $\left(F^{j}=\bar{F}, j=c, m\right)$. In such a case, households do not make any savings; rather, they simply maintain previously accumulated wealth. The wealth share of households is thus fully determined by initial conditions and is not affected by the existence of market power (though market power would still have an impact on the income share of households). However, this scenario is unlikely, as it would require both inflation and real output growth to be systematically zero in the long term.

\subsection{Production function}

Lastly, while explicitly defining a production function is not necessary to derive the solution of the model, this final step allows us to clarify some underlying assumptions about the cost structure of the economy and to close the model. We define the production technology of the economy as a standard Cobb-Douglas production function that converts labour $(L)$ and capital $(K)$ into real output $\left(\mathrm{Y}^{\mathrm{j}} / \mathrm{P}^{\mathrm{j}}\right)$ at constant returns to scale. This means that in the long run, when both labour and capital can be adjusted, the marginal cost is constant and equals average cost.

$$
\frac{Y^{j}}{P^{j}}=A L^{\theta} K^{1-\theta}, \quad j=c, m
$$

Within this production function, A stands for total factor efficiency and it grows at the technological progress rate $g$. Since the stock of capital and labour are assumed stable in steady state, 
in the absence of inflation the total income $Y$ also grows at the rate $g$ (although considering a positive inflation rate or population growth would not affect the solution of the model).

From the production function in equation (16) it is possible to calculate the aggregate labour income $W$, using the fact that in the competitive equilibrium each unit of labour is paid according to its marginal productivity:

$$
W=\frac{\partial Y^{c}}{\partial L} L
$$

Combining equations (16) and (17), and considering that $P^{m}=\mu P^{c}$, the following relationship between the mark-up and the labour share of income holds:

$$
\mu \alpha_{L}=\theta, \quad \text { where } 0<\theta<1 .
$$

Equation (18) implies that, under the law of diminishing marginal productivity of labour $(\theta<$ 1 ), the product of the mark-up by the income share of labour must be lower than one. This is generally true for all countries considered in this paper. As seen next, the term $\mu \alpha_{L}$ plays a fundamental role in the adjustment formula translating the impact of market power on wealth and income inequality.

\subsection{Solving the model}

The system of equations (6), (11) and (15) characterise the equilibrium dynamics of wealth, income and consumption shares. Solving the system with respect to $f_{i}^{c}$ and $y_{i}^{c}$, we obtain our final measure of the redistributive effect of market power on wealth and income (see Annex A4 for a complete derivation):

$$
\begin{gathered}
f_{i}^{c}=f_{i}^{m}+\frac{\frac{s^{\prime}}{\bar{s}}(\mu-1)}{1-\frac{s^{\prime}}{\bar{s}}\left(1-\mu \alpha_{L}\right)}\left(y_{i}^{m}-f_{i}^{m}\right) \\
y_{i}^{c}=y_{i}^{m}+\frac{\mu-1}{1-\frac{s^{\prime}}{\bar{s}}\left(1-\mu \alpha_{L}\right)}\left(y_{i}^{m}-f_{i}^{m}\right) .
\end{gathered}
$$

Equations (19) and (20) provide the simple result that the redistributive effects of market power on wealth and income depend on a few key variables that can be either observed or estimated: a marketpower indicator (mark-up); the income share of labour; the ratio between the average saving rate and the marginal propensity to save; and the observed difference between income and wealth shares in the presence of market power. Moreover, the two equations show that a reduction of market power will increase (decrease) the income and wealth of population groups whose income share exceeds (is less 
then) the corresponding wealth share. These two equations are used to calculate the effects of market power on wealth and income reported in this paper.

\subsection{Lower bounds}

It is possible to simplify the model, with two additional assumptions, in order to obtain an intuitive formula that can be used as a lower bound for the impact of market power on wealth and income inequality. If the marginal propensity to save were to equal the average saving rate - which is the same to say that households consume a constant share of their income - equations (19) and (20) simplify to:

$$
f_{i}^{c}-f_{i}^{m}=y_{i}^{c}-y_{i}^{m}=\frac{\mu-1}{\mu \alpha_{L}}\left(y_{i}^{m}-f_{i}^{m}\right)
$$

Equivalently,

$$
f_{i}^{c}-f_{i}^{m}=y_{i}^{c}-y_{i}^{m}=\frac{L}{\alpha_{L}}\left(y_{i}^{m}-f_{i}^{m}\right)
$$

where $\mathrm{L}$ is the Lerner index. ${ }^{11}$ This suggests that the wealth share difference between the competitive and market power states, for a group $i$, can also be expressed as a differential between its income and wealth shares, increasing as a function of market power, while falling in value as the labour share increases.

Moreover, if we also assume that the marginal productivity of labour is constant, in which case the parameter $\theta$ takes the value 1 , the combinations of equations (18) and (21) leads to the following result:

$$
f_{i}^{c}-f_{i}^{m}=y_{i}^{c}-y_{i}^{m}=(\mu-1)\left(y_{i}^{m}-f_{i}^{m}\right)
$$

While the assumptions that the average saving rate equals the marginal propensity to save and that the marginal productivity of labour is constant are unlikely to be observed in reality, they both reduce the estimated impact of market power to its minimum. Equation (23) hence provides a lower bound for the impact of market power on income and wealth shares. 


\section{Data}

This section describes the variables and data used to calibrate the model and their underlying sources. The eight countries considered have been selected both because of data availability and to ensure geographic breadth. To the extent possible, data sources have been used that are common across these countries to ensure comparability. Data sources are listed in Table 1.

\subsection{Market power indicator}

The extent of market power is measured using mark-ups on average cost reported by Høj et al. (2007), who used the method developed by Roeger (1995) ${ }^{12}$ adapted from Hall (1988) to estimate sector-specific mark-ups for 17 countries, using the OECD-STAN database. The method includes a return on capital that is excluded from the calculation of the mark-up. The data used for these estimates covers the period 1975-2002 and is not purported to represent current mark-ups but rather average mark-ups over that time period in which wealth stocks have been built up. Mark-ups therefore may have changed since then, and the countries with higher mark-ups in these data are not necessarily those with the highest mark-ups now. Arguably, though, these historical mark-ups, which are certainly among the most detailed estimates available, would have played a role in establishing today's wealth distribution.

Mark-ups are imperfect measures of competition, and the estimation method used by Høj et al. is recognised as providing only a first-order approximation. Measurement problems are also observed when working with input and output measures at the sectoral level. Nonetheless, mark-ups are commonly used to measure the strength of competition (Bresnahan, 1989, Schmalansee, 1989). Macroeconomic research in particular often relies on mark-up information to examine the impact of competition on economy wide factors, such as Aghion et al. (2005), Griffiths et al. (2006) and ThumThysen and Canton (2015) and most recently De Loecker and Eeckhout (2017) and Weche and Wambach (2018), for example, which find increased mark-ups in recent times compared to the historical patterns. The mark-ups used in this paper have the feature of extensive sector disaggregation by country while resting in line with those of other authors (e.g., Griffiths et al., 2006); the differences between this paper's competitive and market power mark-ups are no greater than the mark-up differences found in a historical perspective, such as those reported in De Loecker and Eeckhout (2017).

While the mark-ups estimated by Høj et al. (2007) could be directly introduced into the model to measure the total impact of market power on the distribution of wealth, we do not believe that a complete eradication of mark-ups is a viable or desirable policy objective, as some sources of market power include beneficial factors, such as product differentiation and intellectual property rights. Instead, 
we attempt to compare actual mark-ups with the lowest sector specific mark-ups observed across countries, in order to estimate an unexplained or excess mark-up. The model can then simulate the effect of market power by calculating the wealth distribution that would exist if the excess mark-up does not exist.

The estimates of excess mark-up by country-sector are calculated, for each of the 18 sectors, as the difference between the actual mark-up and the lowest observed mark-up across all countries in the sample for each sector. To illustrate, in the sector of wholesale and retail trade and repairs, the mark-up observed in the UK is $16 \%$ and the minimum mark-up (found in Germany) is $12 \%$. The UK excess mark-up for that sector is then calculated as the difference, i.e. 4.0\%. Weighting across excess mark-ups for each sector by output, the average level of the excess mark-up in the UK is $3.9 \%$. The average markups by country (across sectors) are shown in Table 2, with the excess mark-up ranging between 3.9\% and $10.6 \%$.

This method of estimating market power focuses on finding likely cross-country differences in mark-ups, but it is not claimed to serve as a definitive measure of market power for any individual country. Moreover, these measures are not claimed to serve as a current indicator but instead as an approximation of long-run differences of market power across countries, as the underlying data used to estimate the mark-ups covered about 30 years. It is possible that our estimates of excess mark-ups may exceed reported values on corporate profits, because not all profits are captured in corporate profit measures (e.g., partnership income from investment funds or professional service firms) and because a share of profit may be taken in income. Higher than minimal mark-ups, or the excess mark-up, may then be transferred into higher returns to shareholders (and profits), but also potentially into higher income for managers and other employees (e.g., from managerial profit-taking or collective bargaining that extracts part of a monopoly rent). Indeed, in some companies with high profits, such as financial firms, a great part of the income goes to a small, high-earning percentage of the employees, as shown in Denk et al. (2015).

\subsection{Wealth and income shares}

The difference between a population group's share of total income and its share of total wealth is $y_{i}-$ $f_{i} \cdot{ }^{13}$ This difference drives the accumulation of gains from market power for those with a share of business ownership (wealth) that exceeds their share of income, i.e., for $f_{i}>y_{i}$. In contrast, for those with shares of income that exceed their share of business profits, $f_{i}<y_{i}$, the impact of market power will be a net loss in both wealth and income. Intuitively, market power generates a transfer effect from consumers (in proportion to the income they earn) to business owners (in proportion to the wealth or 
capital they hold). This means that the families that lose the most from market power, in absolute as opposed to percentage terms, are likely to be those with a substantial income but low business ownership; this appears consistent with the observation that a "squeezed middle class" has experienced a sustained drop in real income.

Among the 8 countries studied here, wealth asset ownership of the top 1 percentile ranges from $6 \%$ to $37 \%$ of total wealth, while asset ownership of the bottom 80 percentiles ranges from $12 \%$ to $43 \%$ of total. We use wealth asset ownership by wealth group as our indicator of business ownership. The top percentile groups, particularly the $95-99^{\text {th }}$ percentile and the top 1 percentile have an income share of total income that is generally much lower than their percentage of wealth.

These findings support the point that the wealthiest households may receive disproportionately more of the profits from market power than others while not being equally affected by price increases as other groups. We note that the impact of competition on earnings is not unambiguous. Some labour studies find that even some lower-skilled workers may share in supra-competitive rents earned by firms, as discussed in Furman and Orszag (2015). In such cases, the profit transfers that are the basis of the model would be both to business asset owners and to those workers that are in a position to capture the rents earned by the business. This effect is not considered in the model used here; while it may be particularly important in heavily unionised sectors, it may be less important in others and even counterbalanced, from a distributional perspective, for workers who can influence their own pay (such as CEOs and executive teams, or in financial firms, where the key workers benefitting from most profit distribution tend to be a relatively small portion of workers, as shown in Denk et al (2015).

\subsection{Income share of labour}

The income share of labour corresponds to the fraction of total income or output that is earned from labour, usually in the form of wages. The specific measure we use is adjusted for self-employment, whose remuneration is not defined as wages, but which should still be considered as a part of labour income. The data was collected from the Ameco database and it is reported in Krämer (2011). The values are quite stable across countries and they range between 0.62 and 0.7 .

\subsection{Marginal propensity to save over average saving rate}

The marginal propensity to save ( $\left.s^{\prime}\right)$ is the proportion of a marginal increase in household income that is used for saving or, in other words, that is not allocated for consumption. Thus, the marginal propensity to save corresponds to 1 minus the marginal propensity to consume (MPC). The average saving rate $(\bar{s})$ 
is the share of the total income that is saved by the household, that is, it corresponds to the ratio of savings to income.

The ratio of the marginal propensity to save (MPS) to the average saving rate is one of the key parameters of our model. The ratio influences the scale of the impact that market power has on inequality. To ensure that we use the best available evidence for this parameter, we therefore surveyed the literature on savings rates (see annex A6 for more detail).

The issue here is the effect of a permanent and unanticipated reduction of market power on consumption and savings. Reputable studies of permanent and unanticipated changes in income are summarised in Annex A6. Among the studies considered, the average $s^{\prime}$ is 0.16 but this varies across different countries and ranges between 0.11 and 0.23 .

With respect to the average saving rate, we use data collected by national statistical offices for recent decades. The average of these savings rates is 0.11 , and ranges between 0.08 and 0.12 , with the exception of France whose saving rate was around 0.17. The average ratio between the marginal propensity to save (MPS) and the average saving rate for the four countries for which we were able to obtain estimates was 1.9 , though this varied from 1.5 to 2.4. In order to capture a lower bound on the impact, we use a ratio of 1 of the MPS to the average savings rate, though we consider this an unrealistic scenario. For our primary calculations, we use two ratios that are closer to the calculated averages (1.5 and 2).

\section{Results}

The main results on wealth impacts are presented in Table $3 .{ }^{14}$ For each wealth group, actual wealth shares are reported as well as shares absent market power. The range of results that is derived from different ratios of marginal propensity to save over average saving rate is indicated in separate columns.

Table 3 suggests that, in this model and for the countries studied, redistribution from eliminating market power would occur mainly from the wealthiest $10 \%$ of the population to the bottom $80 \%$. Table 4 summarises the percentage of wealth affected by the existence of market power across countries for the wealthiest $10 \%$. For an average country in the sample, $12 \%$ to $21 \%$ of the wealth of the richest $10 \%$ of households (by wealth) reflects the presence of market power. This result is calculated by calibrating the ratio of the marginal propensity to save over the average saving rate between 1.5 and 2 , the values of the ratio most consistent with the available data. Table 4 also reports a lower bound value for the unlikely scenario in which the marginal propensity to save is equal to the average saving rate. In that 
case the wealth attributed to market power would be $6 \%$, showing a non-trivial share of wealth even under the most conservative assumption for the ratio. The differences in the impact of market power across countries arise from the differences in the distribution of wealth and income, observed mark-ups and income shares of labour.

An alternative measure of how market power influences wealth distribution, which does not involve the assumption of a full elimination in market power, is the impact of a reduction in mark-ups by $1 \%$. As an example, a $1 \%$ reduction in mark-ups increases the wealth of the poorest $20 \%$ of the UK population by 0.19 percentage points. Their wealth therefore increases from $0.87 \%$ to $1.06 \%$ (an increase of approximately $22 \%$ ). This marginal effect can be used to estimate the possible impact of reducing or eliminating anti-competitive market power for a given economy-wide price change. The extent to which middle income earners are squeezed by market power varies across countries, as can be seen by focusing on the $20^{\text {th }}$ to $80^{\text {th }}$ percentiles; in general, this group loses from market power, particularly between the $20^{\text {th }}$ to $60^{\text {th }}$ percentiles, which would see their share of wealth rise from $14.0 \%$ to $20.7 \%$ on average absent market power, amounting to a $48 \%$ increase in wealth share.

In addition to looking at the impact on wealth, we also show in Table 5 how market power affects the income shares of the population groups in each country, while Table 6 summarises the percentage change in the income of the poorest $20 \%$ for all countries. In an average country in the sample, for a range of reasonable assumptions about saving behaviour, the income of the poorest $20 \%$ of households is expected to rise by more than $11 \% .{ }^{15}$ We note that the income effects are particularly meaningful for the poorest households, which often hold close-to-zero or even negative levels of wealth.

Finally, the redistribution of income resulting from a reduction in mark-ups by $1 \%$ can be derived. Taking again the case of the United Kingdom, a 1\% reduction in mark-ups increases the income of the poorest $20 \%$ of the UK population by 0.12 percentage points. Their income share therefore increases from $7.8 \%$ to $7.92 \%$ (an increase of approximately $1.5 \%$ ).

\section{Conclusions}

This paper provides evidence that market power can contribute substantially to wealth inequality, augmenting wealth of the richest $10 \%$ of the population on average by $12 \%$ to $21 \%$, depending on the choice of key model parameters relating to saving behaviour, and reducing the income of the poorest $20 \%$ of the population by $11 \%$ or more. The groups of the population who are typically harmed by market power are the 0 to $80^{\text {th }}$ percentiles, and interestingly the harm appears to be particularly accentuated on a middle class comprised somewhere between the $20^{\text {th }}$ to $60^{\text {th }}$ percentiles. There are also 
differences in the magnitude of the effect of market power across countries, which are explained by differences in mark-ups, as well as disparities in the wealth distributions across jurisdictions. Arguably, these findings may inform the case for focusing on consumer welfare standards for policy decisionmaking, as total welfare standards can yield substantially different policy outcomes, and distributional impacts, for the benefit of only a relatively small share of the population.

While the model proposed in this paper intends to provide a rough measure of the overall effect of market power on inequality it is important to note that the figures reported are in some respects quite conservative. For instance, by assuming that market power affects all prices in the same proportion, the model fails to account for the ways that prices may become particularly inflated for the most essential and inelastic goods, reinforcing thereby the harm to the poor. Likewise, our results might be underestimated due to the fact that market power may not only increase the prices of final goods, but may also limit wage growth, thus reinforcing inequality.

Moreover, although all forms of market power can generally exacerbate inequality, this is not to suggest that market power is always undesirable. There are many generally considered legitimate sources of market power, such as intellectual property protection for products, processes or brands, which protect the process of innovation. However, violations of competition law, government-created barriers to entry or natural monopolies may be significant sources of market power that reinforce inequality without a positive trade-off on innovation.

Overall, these findings suggest several valuable avenues for future research. First, extending the analysis to developing countries would be interesting, which should be possible as data measuring inequality are rapidly becoming more easily available. Second, more work is needed to understand the likely scale of legitimate and illegitimate sources of market power. Such figures would provide an underpinning for one of the key variables for this analysis. Third, using econometric techniques to regress wealth on measures of market power would be of substantial value, allowing one to obtain confidence intervals for these figures. 


\section{Notes}

${ }^{1}$ See, for example, Atkinson (2008), Piketty (2014), Piketty and Saez (2003), and OECD (2015).

${ }^{2}$ That is, returns above the market return, which should be competed down to the cost of capital.

${ }^{3}$ See, for example, Furman and Orszag (2015) on regulatory sources of market power and Baker and Salop (2015) on competition law violations.

${ }^{4}$ For Korea and Japan, the sources are listed in Table 1. Other sources such as CSFB report higher estimates of wealth and financial wealth for the top $1 \%$ in these two countries in particular.

${ }^{5}$ For example, Farrell and Shapiro (1990) suggest that horizontal mergers would often increase total welfare that includes firm profits, while not consumer welfare, so the choice of standard has a significant impact on outcomes. Katz and Shelanski (2005) and Shapiro (2012) suggest that innovations tend to generate total welfare gains that include a large element of profit from intellectual property, potentially diluting the strength of some of the arguments for the benefits of innovation.

${ }^{6}$ On the one hand, low mark-ups may indicate a declining industry with uneconomic return on capital. On the other hand, the lowest mark-ups in an industry may already be expected to include some market power, to the extent that sector-wide perfect competition is rare.

${ }^{7}$ This assumption can be relaxed to yield marginal propensities to save that vary across wealth classes, but we note that this adjustment would actually imply higher shares of marginal savings for the highest wealth classes, further increasing the strength of the results reported below. The assumption is thus conservative, even if an over-simplification.

${ }^{8}$ Market power may potentially be shared with employees, including lesser paid workers. If the workers, notably, receive a substantial increase in their incomes as a result of market power, the distribution of profits will go not only to those with substantial net wealth but also to those without, thus weakening the result of this paper. While this point is important to consider, to the extent that union negotiating power has declined over time, and that top management pay has substantially outpaced inflation, redistribution via labour income, to the extent it occurs, may be accruing increasingly to the wealthiest workers (i.e., management)

${ }^{9}$ In the linear expenditure model, households' utility from consumption and saving is described by the following equation: $U(C, S)=\left(1-s^{\prime}\right) \ln (C-a)+s^{\prime} \ln (S)$. The maximisation of this utility function subject to the budget constrains yields the consumption function presented in equation (7).

${ }^{10}$ Consider that the dynamics of wealth are described by the difference equation $F_{t+1}=F_{t}+Y_{t}-C_{t}$. That is, the wealth accumulated in any period of time is equal to the wealth held in the previous period plus aggregate savings. Then, assuming that the economy grows at the exogenous growth rate $g$, the equilibrium solution of the difference equation is given by $F_{t+1}=F_{t}(1+g)$ and, in steady-state, equation (12) holds.

${ }^{11}$ The Lerner index is equal to $\frac{P-C}{P}$, where $P$ is the price and $C$ the marginal cost, which in this case equals the average cost.

${ }^{12}$ Prior work using Roeger's approach has included Oliveira Martins et al. (1996).

${ }^{13}$ While the population of the top wealth decile and top consumption decile are not perfectly overlapping, the authors believe there is a high correlation between consumption shares of the income for those persons in the $\mathrm{x}^{\text {th }}$ wealth decile and those in the $\mathrm{x}^{\text {th }}$ income decile. This approximation is used because data on 
the consumption shares of the top wealth decile was unavailable to the authors at the time of writing. Note that for Korea, Japan and the U.S., the consumption of the top 1 percentile had to be calibrated based on consumption shares in known countries.

${ }^{14}$ The data from Japan have a different source which is listed in Table 1.

15 The income variations observed for the bottom quintiles of the population may actually exceed the price change percentage from reduced market power. This follows from the fact that wealth is an endogenous variable in the proposed model, meaning that the real income increase from absence of market power enables the bottom quintile of the population to save more and subsequently receive extra returns on wealth. As an illustrative example, in a country where prices fall by $1 \%$ as a result of pro-competitive policies, a household that initially does not hold wealth obtains an immediate raise in real income by $1 \%$, allowing it to save more, accumulate wealth and raise future real income. 


\section{References}

Aghion, P., N. Bloom, R. Blundell, R. Griffith and P. Howitt (2005), "Competition and Innovation: An Inverted-U Relationship”, The Quarterly Journal of Economics, Vol. 120, No. 2, pp. 701728.

Atkinson, A. B. (2008). The changing distribution of earnings in OECD countries. Oxford New York: Oxford University Press.

Baker, J. B. and S. C. Salop (2016), "Antitrust, Competition Policy, and Inequality", The Georgetown Law Journal, Vol. 104, No. 1, pp. 1-28.

Bresnahan, T. (1989), "Empirical Methods for Industries with Market Power", in R. Schmalansee and R. Willig (eds.), Handbook of Industrial Organisation, North-Holland, Amsterdam.

Comanor, W. S. and R. H. Smiley (1975), "Monopoly and the Distribution of Wealth", The Quarterly Journal of Economics, Vol. 89, No. 2, pp. 177-194.

Creedy, J. and R. Dixon (1999), “The Distributional Effects of Monopoly", Australian Economic Papers, Vol. 38, No. 3, pp. 223-237.

De Loecker, J. and J. Eeckhout (2017), "The Rise of Market Power and the Macroeconomic Implications", NBER Working Paper.

Denk, O., S. Schich and B. Cournède (2015), "Why Implicit Bank Debt Guarantees Matter: Some Empirical Evidence", OECD Journal: Financial Market Trends, Vol. 2014/2.

Dynan, K. E., J. Skinner and S. P. Zeldes (2004), “Do the Rich Save More?”, Journal of Political Economy, Vol. 112, No. 2, pp. 397-444.

Ennis, S. (2014), "Commerce Affected by Cross-Border Private Cartels", OECD WP3 paper, DAF/COMP/WP3(2014)11.

Ennis, S. and Y. Kim (2017) "Market Power and Wealth Distribution" in OECD and World Bank, A Step Ahead: Competition Policy, Shared Prosperity and Inclusive Growth, World Bank Publishing, Washington, D.C.

Farrell, J. and C. Shapiro (1990) "Horizontal Mergers: An Equilibrium Analysis", American Economic Review, 80(1), pp. 107-126.

Furman, J. and P. Orszag (2015), "A Firm-Level Perspective on the Role of Rents in the Rise in Inequality", Presentation at A Just Society Centennial Event in Honor of Joseph Stiglitz at Columbia University.

Griffith. R., R. Harrison and H. Simpson (2006), "The Link between Product Market Reform, Innovation and EU Macroeconomic Performance", European Commission Economics Papers, No. 243.

Gutiérrez, G and T. Phillippon, (2016) “Investment-less Growth: An Empirical Investigation”, NBER Working Paper No. 22897. 
Gutiérrez, G. (2017) “Investigating Global Labour and Profit Shares”, NYU Working Paper.

Hausman, J. A. and J. G. Sidak (2004), "Why Do the Poor and the Less-Educated Pay More for LongDistance Calls?", Contributions in Economic and Policy Research, Vol. 3, No. 1, pp. 1-26.

Hall, R. (1988), "The Relation between Price and Marginal Cost in U.S. Industry”, Journal of Political Economy, Vol. 96, pp. 921-947.

Høj, J., M. Jimenez, M. Maher, G. Nicoletti and M. Wise (2007), "Product Market Competition in the OECD Countries: Taking Stock and Moving Forward", OECD Economics Department Working Papers, No. 575, OECD Publishing, Paris.

Katz, M., and H. Shelanski. 2005. "Merger Policy and Innovation: Must Enforcement Change to Account for Technological Change?" In Innovation Policy and the Economy, ed. Adam Jaffe, Joshua Lerner, and Scott Stern. Cambridge, Massachusetts: MIT Press.

Krämer, H. (2011), "Bowley's Law: The Diffusion of an empirical supposition into Economic Theory", Cahiers d'Économie Politique Papers in Political Economy, vol. 61.

Leipziger, D. M. et al. (1992), “The Distribution of Income and Wealth in Korea”, EDI Development Studies, World Bank, Washington, D.C..

OECD (2015) In it together: why less inequality benefits all. OECD Publishing, Paris.

Oliveira Martins, J. S. Scarpetta and D. Pilat (1996), "Mark-Up Ratios in Manufacturing Industries: Estimates for 14 OECD Countries", OECD Economics Department Working Papers, No. 162, OECD Publishing.

Piketty, T. and E. Saez (2003), "Income Inequality in the United States, 1913-1998", The Quarterly Journal of Economics, Vol. 118, No. 1, pp. 1-39.

Piketty, T. (2014), Capital in the $21^{\text {st }}$ Century, Cambridge, Massachusetts: Harvard University Press.

Rognlie, M. (2015), "Deciphering the Fall and Rise in the Net Capital Share”, Brookings Papers on Economic Activity, Brookings BPEA Conference, March.

Roeger, W. (1995), "Can Imperfect Competition Explain the Difference between Primal and Duel Productivity Measures? Estimates for U.S. Manufacturing", Journal of Political Economy, Vol. 103, No. 2. pp. 316-330.

Schmalansee, R. (1989), "Inter-Industry Studies of Structure and Performance", in R. Schmalansee and R. Willig (eds.), Handbook of Industrial Organisation, North-Holland, Amsterdam.

Shapiro, C. (2012) "Competition and Innovation: Did the Arrow Hit the Bull's Eye", in The Rate and Direction of Inventive Activity Revisited. Ed. Josh Lerner and Scott Stern. Chicago: University of Chicago Press.

Thum-Thysen, A and E. Canton (2015), "Estimation of Service Sector Mark-ups Determined by Structural Reform Indicators", European Commission Economic Papers, No. 547. 
Weche, J. P. and A. Wambach (2018), "The Fall and Rise of Market Power in Europe”, Working Paper Series in Economics 379, University of Lüneberg, Institute of Economics.

Wölfl, A., I. Wanner, O. Röhn and G. Nicoletti (2010), "Product Market Regulation: Extending the Analysis Beyond OECD Countries", OECD Economics Department Working Papers, No. 799, OECD Publishing, Paris. 
From rewriting equation (2), note that:

$$
R^{c}=Y^{c}-W
$$

From dividing equation (1) by $\mu$,

$$
Y^{c}=\frac{Y^{m}}{\mu}
$$

Combining the two previous equations:

$$
R^{c}=\frac{Y^{m}}{\mu}-W
$$

Noting from (2) that:

$$
Y^{m}=W+R^{m}
$$

Using equation (2) to substitute $Y^{m}$ in the prior equation:

$$
R^{c}=\frac{W+R^{m}}{\mu}-W .
$$

Re-arranging and multiplying $\mathrm{W}$ by $\frac{\mu}{\mu}$, we obtain:

$$
R^{c}=\frac{W}{\mu}-\frac{\mu W}{\mu}+\frac{R^{m}}{\mu} .
$$

Finally, the last equation can be simplified to:

$$
R^{c}=\frac{(1-\mu)}{\mu} W+\frac{R^{m}}{\mu} .
$$




\section{Annex A1. Derivation of equation (6)}

Subtracting equation (5) from equation (4):

$$
y_{i}^{m} Y^{m}-y_{i}^{c} Y^{c}=W_{i}+f_{i}^{m} R^{m}-W_{i}-f_{i}^{c}\left[\frac{1-\mu}{\mu} W+\frac{R^{m}}{\mu}\right] .
$$

Eliminating $W_{i}$ :

$$
y_{i}^{m} Y^{m}-y_{i}^{c} Y^{c}=f_{i}^{m} R^{m}-f_{i}^{c}\left[\frac{1-\mu}{\mu} W+\frac{R^{m}}{\mu}\right] .
$$

Removing $f_{i}^{c} W$ from the last term and using equation (1) to replace $Y^{c}$ with $\frac{Y^{m}}{\mu}$ :

$$
y_{i}^{m} Y^{m}-y_{i}^{c} \frac{Y^{m}}{\mu}=f_{i}^{m} R^{m}+f_{i}^{c} W-f_{i}^{c} \frac{1}{\mu}\left(W+R^{m}\right) .
$$

Using equation (2) for $j=m$ (i.e. $Y^{m}=W+R^{m}$ ):

$$
y_{i}^{m} Y^{m}-y_{i}^{c} \frac{Y^{m}}{\mu}=f_{i}^{m}\left(Y^{m}-W\right)+f_{i}^{c} W-f_{i}^{c} \frac{Y^{m}}{\mu} .
$$

Multiplying all terms by $\mu$ and dividing by $Y^{m}$ :

$$
\mu y_{i}^{m}-y_{i}^{c}=\mu f_{i}^{m}\left(1-\frac{W}{Y^{m}}\right)+\mu f_{i}^{c} \frac{W}{Y^{m}}-f_{i}^{c} .
$$

Defining the labour share of income, $\frac{W}{Y^{m}}$, as $\alpha_{L}$ :

$$
\mu y_{i}^{m}-y_{i}^{c}=\mu\left(1-\alpha_{L}\right) f_{i}^{m}+\mu \alpha_{L} f_{i}^{c}-f_{i}^{c} .
$$

Rearranging the terms:

$$
y_{i}^{m}-y_{i}^{c}=(1-\mu) y_{i}^{m}+\mu\left(1-\alpha_{L}\right) f_{i}^{m}-\left(1-\mu \alpha_{L}\right) f_{i}^{c} .
$$

Adding and subtracting $(1-\mu) f_{i}^{m}$ to the right-hand side of the previous equation:

$$
y_{i}^{m}-y_{i}^{c}=(1-\mu) y_{i}^{m}-(1-\mu) f_{i}^{m}+\left(1-\mu+\mu\left(1-\alpha_{L}\right)\right) f_{i}^{m}-\left(1-\mu \alpha_{L}\right) f_{i}^{c} .
$$

Simplifying the third term from the right-hand side of the last equation:

$$
y_{i}^{m}-y_{i}^{c}=(1-\mu) y_{i}^{m}-(1-\mu) f_{i}^{m}+\left(1-\mu \alpha_{L}\right) f_{i}^{m}-\left(1-\mu \alpha_{L}\right) f_{i}^{c} .
$$

Finally, rearranging:

$$
y_{i}^{m}-y_{i}^{c}=(\mu-1)\left(f_{i}^{m}-y_{i}^{m}\right)+\left(1-\mu \alpha_{L}\right)\left(f_{i}^{m}-f_{i}^{c}\right) .
$$




\section{Annex A2. Derivation of equation (11)}

Multiplying equation (9) by $\mu$ and subtracting it from equation (10):

$$
c_{i}^{m} C^{m}-c_{i}^{c} \mu C^{c}=\bar{C}_{i}^{m}-\mu \bar{C}_{i}^{c}+\left(1-s^{\prime}\right) y_{i}^{m} Y^{m}-\left(1-s^{\prime}\right) y_{i}^{c} \mu Y^{c} .
$$

Taking into account that, as follows from equation (1), aggregate nominal variables under market power are equal to the nominal variables under competition times the mark-up:

$$
c_{i}^{m} C^{m}-c_{i}^{c} C^{m}=\bar{C}_{i}^{m}-\mu \bar{C}_{i}^{c}+\left(1-s^{\prime}\right) y_{i}^{m} Y^{m}-\left(1-s^{\prime}\right) y_{i}^{c} Y^{m} .
$$

Likewise, because real autonomous consumption is not affected by income or wealth, its value is constant in steady-state. Therefore, the same relation between nominal autonomous consumption under competition and market power holds $\bar{C}_{i}^{m}-\mu \bar{C}_{i}^{c}$ :

$$
c_{i}^{m} C^{m}-c_{i}^{c} C^{m}=\bar{C}_{i}^{m}-\bar{C}_{i}^{m}+\left(1-s^{\prime}\right) y_{i}^{m} Y^{m}-\left(1-s^{\prime}\right) y_{i}^{c} Y^{m} .
$$

Isolating the common factors:

$$
\left(c_{i}^{m}-c_{i}^{c}\right) C^{m}=\left(1-s^{\prime}\right)\left(y_{i}^{m}-y_{i}^{c}\right) Y^{m} .
$$

Dividing both sides of the equation by $C^{m}$ :

$$
\left(c_{i}^{m}-c_{i}^{c}\right)=\left(1-s^{\prime}\right)\left(y_{i}^{m}-y_{i}^{c}\right) \frac{Y^{m}}{C^{m}} .
$$

Using the fact that, by definition, $1-\bar{s}=\frac{C^{m}}{Y^{m}}$ :

$$
\left(c_{i}^{m}-c_{i}^{c}\right)=\left(1-s^{\prime}\right)\left(y_{i}^{m}-y_{i}^{c}\right) \frac{Y^{m}}{(1-\bar{s}) Y^{m}} .
$$

Rearranging the terms:

$$
\left(c_{i}^{m}-c_{i}^{c}\right)=\frac{1-s^{\prime}}{1-\bar{s}}\left(y_{i}^{m}-y_{i}^{c}\right) .
$$




\section{Annex A3. Derivation of equation (15)}

Multiplying all terms of equation (13) by $\mu$ and subtracting them from equation (14), one can show that:

$$
f_{i}^{m} F^{m}-f_{i}^{c} \mu F^{c}=\frac{y_{i}^{m} Y^{m}-y_{i}^{c} \mu Y^{c}-c_{i}^{m} C^{m}+c_{i}^{c} \mu C^{c}}{g} .
$$

Using the relations described in equation (1):

$$
f_{i}^{m} F^{m}-f_{i}^{c} F^{m}=\frac{y_{i}^{m} Y^{m}-y_{i}^{c} Y^{m}-c_{i}^{m} C^{m}+c_{i}^{c} C^{m}}{g} .
$$

Isolating the common factors:

$$
\left(f_{i}^{m}-f_{i}^{c}\right) F^{m}=\frac{\left(y_{i}^{m}-y_{i}^{c}\right) Y^{m}-\left(c_{i}^{m}-c_{i}^{c}\right) C^{m}}{g} .
$$

Rearranging and using the equilibrium solution of wealth dynamics in equation (12):

$$
f_{i}^{m}-f_{i}^{c}=\frac{\left(y_{i}^{m}-y_{i}^{c}\right) Y^{m}-\left(c_{i}^{m}-c_{i}^{c}\right) C^{m}}{Y^{m}-C^{m}} .
$$

Substituting $C^{m}$ by $(1-\bar{s}) Y^{m}$ :

$$
f_{i}^{m}-f_{i}^{c}=\frac{\left(y_{i}^{m}-y_{i}^{c}\right) Y^{m}-\left(c_{i}^{m}-c_{i}^{c}\right)(1-\bar{s}) Y^{m}}{Y^{m}-(1-\bar{s}) Y^{m}} .
$$

Dividing all terms of the right-hand side of the equation by $Y^{m}$ :

$$
f_{i}^{m}-f_{i}^{c}=\frac{\left(y_{i}^{m}-y_{i}^{c}\right)-\left(c_{i}^{m}-c_{i}^{c}\right)(1-\bar{s})}{1-(1-\bar{s})} .
$$

Finally, simplifying the last expression:

$$
f_{i}^{m}-f_{i}^{c}=\frac{1}{\bar{s}}\left(y_{i}^{m}-y_{i}^{c}\right)-\frac{1-\bar{s}}{\bar{s}}\left(c_{i}^{m}-c_{i}^{c}\right) .
$$


Introducing the right-hand side of equation (11) into equation (15)

$$
f_{i}^{m}-f_{i}^{c}=\frac{1}{\bar{s}}\left(y_{i}^{m}-y_{i}^{c}\right)-\frac{1-\bar{s}}{\bar{s}} \frac{1-s^{\prime}}{1-\bar{s}}\left(y_{i}^{m}-y_{i}^{c}\right) .
$$

Simplifying the expression:

$$
f_{i}^{m}-f_{i}^{c}=\frac{s^{\prime}}{\bar{s}}\left(y_{i}^{m}-y_{i}^{c}\right)
$$

Introducing the previous result into equation (6)

$$
y_{i}^{m}-y_{i}^{c}=(\mu-1)\left(f_{i}^{m}-y_{i}^{m}\right)+\left(1-\mu \alpha_{L}\right) \frac{s^{\prime}}{\bar{s}}\left(y_{i}^{m}-y_{i}^{c}\right) .
$$

Rearranging the terms, we obtain equation (20):

$$
y_{i}^{m}-y_{i}^{c}=\frac{\mu-1}{1-\frac{s^{\prime}}{\bar{s}}\left(1-\mu \alpha_{L}\right)}\left(f_{i}^{m}-y_{i}^{m}\right) .
$$

Finally, combining equation (20) and the previous result $f_{i}^{m}-f_{i}^{c}=\frac{s^{\prime}}{\bar{s}}\left(y_{i}^{m}-y_{i}^{c}\right)$, one gets equation (19):

$$
f_{i}^{m}-f_{i}^{c}=\frac{\frac{s^{\prime}}{\bar{s}}(\mu-1)}{1-\frac{s^{\prime}}{\bar{s}}\left(1-\mu \alpha_{L}\right)}\left(f_{i}^{m}-y_{i}^{m}\right)
$$




\section{Annex A5. Estimating competitive mark-ups}

In this annex we set out the methodology for estimating a competitive mark-up against which to compare estimated actual mark-ups. We obtained estimates of the price mark-up over average cost for 18 sectors across 17 countries from Høj et al. (2007). We drop Luxembourg as an outlier due to its small size. See Table A5.1 below.

Table A5.1. Mark-ups estimates: industry detail

\begin{tabular}{|c|c|c|c|c|c|c|c|c|c|c|c|c|c|c|c|c|c|}
\hline & AUT & BEL & CAN & DEU & DNK & ESP & FIN & FRA & GBR & ITA & JPN & KOR & LUX & NLD & NOR & SWE & USA \\
\hline All manufacturing ${ }^{2}$ & 0.15 & 0.10 & 0.15 & 0.13 & 0.11 & 0.14 & 0.18 & 0.12 & 0.11 & 0.15 & 0.09 & 0.12 & 0.07 & 0.13 & 0.13 & 0.11 & 0.12 \\
\hline Fragmented-Low $R \& D$ industries ${ }^{2}$ : & 0.16 & 0.11 & 0.19 & 0.14 & 0.13 & 0.16 & 0.21 & 0.12 & 0.12 & 0.18 & 0.08 & 0.12 & 0.04 & 0.16 & 0.13 & 0.10 & 0.13 \\
\hline Textiles, wearing apparel, leather & 0.13 & 0.05 & 0.13 & 0.14 & 0.12 & 0.13 & 0.14 & 0.09 & 0.10 & 0.16 & 0.06 & 0.12 & & 0.14 & 0.12 & & 0.09 \\
\hline Wood and wood products & 0.10 & 0.12 & 0.25 & 0.14 & 0.18 & 0.16 & 0.19 & 0.05 & 0.16 & 0.22 & 0.05 & 0.13 & -0.03 & 0.08 & 0.11 & & 0.19 \\
\hline Pulp, paper, printing and publishing & 0.19 & 0.14 & 0.20 & 0.19 & 0.10 & 0.18 & 0.23 & 0.13 & 0.12 & 0.18 & 0.10 & 0.11 & 0.10 & 0.20 & 0.14 & & 0.13 \\
\hline Other non-metallic mineral products & 0.24 & 0.17 & 0.22 & 0.19 & 0.17 & 0.19 & 0.24 & 0.16 & 0.16 & 0.22 & 0.15 & 0.18 & 0.03 & 0.20 & 0.14 & 0.05 & 0.17 \\
\hline Fabricated metal products & 0.13 & & 0.13 & 0.07 & & & 0.16 & & & 0.19 & 0.01 & 0.10 & 0.03 & 0.11 & 0.13 & 0.12 & 0.12 \\
\hline Segmented-Low $R \& D$ industries ${ }^{2}$ : & 0.17 & 0.09 & 0.14 & 0.13 & 0.08 & 0.13 & 0.13 & 0.14 & 0.11 & 0.13 & 0.08 & 0.09 & 0.12 & 0.13 & 0.14 & 0.11 & 0.09 \\
\hline Food, beverages and tobacco & 0.13 & 0.09 & 0.13 & 0.12 & 0.08 & 0.13 & 0.10 & 0.14 & 0.11 & 0.14 & 0.07 & 0.05 & 0.13 & 0.12 & 0.08 & 0.08 & 0.09 \\
\hline Basic metals & 0.25 & & 0.17 & 0.18 & & & 0.18 & & & 0.10 & 0.10 & 0.14 & 0.11 & 0.24 & 0.27 & 0.16 & 0.08 \\
\hline Fragmented-High R\&D industries ${ }^{2}$ : & 0.16 & 0.12 & 0.13 & 0.13 & 0.11 & 0.15 & 0.17 & 0.17 & 0.12 & 0.16 & 0.09 & 0.11 & 0.06 & 0.13 & 0.09 & 0.13 & 0.10 \\
\hline Machinery and equipment & 0.19 & 0.20 & 0.16 & 0.13 & 0.09 & & 0.17 & 0.19 & 0.12 & 0.15 & 0.08 & 0.11 & 0.08 & 0.15 & 0.09 & 0.13 & \\
\hline Other manufacturing and recycling & 0.09 & 0.06 & 0.08 & 0.16 & 0.15 & 0.15 & 0.17 & 0.13 & 0.13 & 0.17 & 0.11 & 0.11 & -0.05 & 0.10 & 0.09 & & 0.10 \\
\hline Segmented-High $R \& D$ industries ${ }^{2}$ : & 0.13 & 0.09 & 0.12 & 0.13 & 0.11 & 0.14 & 0.18 & 0.12 & 0.11 & 0.14 & 0.10 & 0.13 & 0.03 & 0.12 & 0.14 & 0.12 & 0.13 \\
\hline Chemical, plastics, rubber and fuel products & 0.11 & 0.09 & 0.12 & 0.16 & 0.11 & 0.17 & 0.15 & 0.11 & 0.12 & 0.13 & 0.10 & 0.14 & 0.03 & 0.13 & 0.18 & 0.15 & 0.15 \\
\hline Electrical and optical equipment & 0.15 & & 0.14 & 0.13 & 0.12 & & 0.22 & 0.15 & 0.13 & 0.17 & 0.13 & 0.12 & & 0.09 & 0.12 & 0.12 & \\
\hline Transport equipment & 0.14 & 0.09 & 0.13 & 0.09 & 0.08 & 0.11 & 0.17 & 0.11 & 0.07 & 0.14 & 0.08 & 0.11 & 0.02 & 0.09 & 0.11 & 0.08 & 0.10 \\
\hline Non-manufacturing ${ }^{1.2}$ & 0.28 & 0.20 & 0.20 & 0.25 & 0.25 & & 0.27 & 0.26 & 0.16 & 0.38 & 0.26 & 0.32 & 0.22 & 0.24 & 0.26 & 0.17 & 0.19 \\
\hline Electricity, gas and water supply & 0.34 & 0.23 & 0.35 & 0.37 & 0.41 & & 0.37 & 0.27 & 0.15 & 0.30 & 0.46 & 0.32 & & 0.19 & 0.48 & & 0.20 \\
\hline Wholesale and retail trade, repairs & 0.28 & & 0.1 & 0.12 & 0.28 & & 0.25 & 0.25 & 0.16 & 0.45 & & & 0.24 & 0.30 & 0.24 & & 0.14 \\
\hline Transport and storage & 0.14 & & 0.26 & 0.13 & 0.18 & & 0.33 & 0.22 & 0.10 & & 0.17 & & & 0.21 & 0.27 & 0.18 & 0.16 \\
\hline Post and telecommunications & 0.20 & & 0.35 & 0.38 & 0.24 & & 0.36 & 0.40 & 0.21 & & 0.32 & & & 0.26 & 0.29 & & 0.28 \\
\hline Financial intermediation & 0.37 & & 0.14 & 0.18 & 0.35 & & 0.34 & 0.20 & 0.21 & 0.32 & 0.27 & & 0.21 & 0.33 & 0.34 & & 0.25 \\
\hline Business services & 027 & & & 0.44 & 020 & & 019 & 028 & & & 016 & & 019 & 012 & 016 & 014 & 020 \\
\hline
\end{tabular}

(1) Non-manufacturing excludes construction, real estate activities and personal services.

(2) Averages using sectoral production as weights. Weights are country-specific.
(3) Unweighted average.

Source: OECD STAN database and Secretariat calculations.

By comparing the mark-ups across different countries, we identified the lowest, most competitive mark-up in each sector. For each sector we then calculate the difference between a countries' mark-up and the lowest observed mark-up. For example, in the sector of wholesale and retail trade and repairs, the lowest mark-up (found in Germany) is 12\% while Canada has a mark-up of $16 \%$ in that sector. We then say that Canada faces a $4 \%$ excess mark-up in that sector. We average these excess mark-ups across sectors to find Canada's average excess mark-up (which is 9.67\%). We also calculate a weighted average excess mark-up for each country by using the OECD's STAN database to identify a country specific weight for each sector in each country (this reduces the excess mark-up in Canada to $7.58 \%)$.

In notation, the observed mark-up in sector $o$ and country $n$ (with whatever market power exists in a sector) is $\mu_{o, n}^{m}$. The minimum (most competitive) mark-up found across all countries $n$ (from $n=1$ to $N$ ) for sector $o$ is: 


$$
u_{o}^{c}=\min \left\{u_{o, 1}^{m}, u_{o, 2}^{m}, \ldots, u_{o, N}^{m}\right\}
$$

That is, we take the most competitive mark-up for a sector to be the minimum observed for that sector across all countries in the sample. To the extent that a fully competitive situation is unlikely, except for commodity products, this minimum observed mark-up is a conservative (i.e., high) estimate of the competitive mark-up. The excess mark-up for a given sector $o$ in a given country $n$ is the difference between the observed mark-up for sector $o$ in country $n$ and the minimum mark-up for sector $o$ in all countries:

$$
\mu_{o, n}^{e}=\mu_{o, n}^{m}-\mu_{o}^{c}
$$

To arrive at a figure representing a country's overall excess mark-up, we weight the excess mark-up for each sector by the size of that sector $\left(e_{o, n}\right)$ in that country's economy, yielding a weighted excess mark-up of:

$$
\mu_{n}^{e}=\sum_{o=1}^{O} e_{o, n} \mu_{o, n}^{e}
$$

Table 2 presents the results. Since we use differences in the sector mark-ups between countries, we are able to ensure that the results are not driven by the variations in mark-ups across sectors. "Competitive mark-ups" are estimated using the minimum mark-ups observed across countries. They are probably overestimated since market-based sectors are, over the long run, unlikely to have any sector level mark-ups below the competitive level. If competitive mark-ups are, in fact, overestimated, than the price change attributed to market-power is underestimated and the redistribution effect is also underestimated, meaning that our results are conservative. 


\section{Annex A6. The marginal propensity to save}

The ratio of the marginal propensity to save to the average savings rate is a key parameter of the model to examine the effects of market power. Table A6.1 sets out the results of our literature survey of estimates of the marginal propensity to save (MPS) from a permanent shock in income. Table A6.2 set out estimates of the average saving rate from countries with an estimate of MPS, and calculates the value of the ratio where possible. It identifies the ratio for the average country as 1.9.

Table A6.1. Marginal propensity to save (MPS) from a permanent shock in income

\begin{tabular}{|c|c|c|c|}
\hline Data & Source and Link & $\begin{array}{c}\text { MPS } \\
(\%)\end{array}$ & $\begin{array}{c}\text { MPS } \\
\text { (range) }\end{array}$ \\
\hline $\begin{array}{l}\text { United States. Household data from the } \\
\text { Consumer Expenditure Survey, Survey of } \\
\text { Consumer Finances and Panel Study of } \\
\text { Income Dynamics. The MPS range was } \\
\text { extracted from the first column in Table } 9 \text {. The } \\
\text { central value corresponds to the average of all } \\
\text { reported figures. }\end{array}$ & $\begin{array}{l}\text { Dynan, K. E., J. Skinner and S. P. Zeldes (2004), } \\
\text { "Do the rich save more?", Journal of Political } \\
\text { Economy, Vol. 112, No. 2, pp. 397-444. } \\
\text { http://www.jstor.org/stable/pdf/10.1086/381475.pdf } \\
\text { ?acceptTC=true }\end{array}$ & 14 & {$[7-25]$} \\
\hline $\begin{array}{l}\text { United States. Data collected from lottery } \\
\text { players in Massachusetts in the } 80 \text { s. For the } \\
\text { authors' preferred specification, the MPS is } \\
\text { estimated at } 16 \% \text { (Table } 6-\text { the authors } \\
\text { appear to discard lower values obtained with } \\
\text { other specifications). Excluding retirement } \\
\text { accounts, the estimate is } 18 \% \text {. Also, a } \\
\text { calibration of their life-cycle model suggests } \\
\text { an MPS around } 15 \% \text {. }\end{array}$ & $\begin{array}{l}\text { Imbens, G. W., D. B. Rubin and B. I. Sacerdote } \\
\text { (2001), "Estimating the effect of unearned income } \\
\text { on labor earnings, savings, and consumption: } \\
\text { evidence from a survey of lottery players", The } \\
\text { American Economic Review, Vol. } 91 \text {, No. 4, pp. 778- } \\
794 \text {. } \\
\text { http://www.jstor.org/stable/pdf/2677812.pdf?accept } \\
\underline{\text { TC=true }}\end{array}$ & 16 & [15-18] \\
\hline $\begin{array}{l}\text { United Kingdom. This paper uses micro data } \\
\text { to estimate permanent income as a function of } \\
\text { human capital, which is then used to estimate } \\
\text { the marginal propensity to save out of } \\
\text { permanent shocks. Average MPS found is } \\
18 \% \text { and, among all specifications, it ranges } \\
\text { between 5\% and 30\%. }\end{array}$ & $\begin{array}{l}\text { Miles, D. (1997), "A Household Level Study of the } \\
\text { Determinants of Incomes and Consumption", The } \\
\text { Economic Journal, Vol. 107, No. 440, pp. 1-25. } \\
\text { http://www.jstor.org/stable/pdf/2235268.pdf }\end{array}$ & 18 & {$[5-30]$} \\
\hline $\begin{array}{l}\text { United States. Friedman's estimation of the } \\
\text { MPC out of a permanent income, using annual } \\
\text { per capita data for the period } 1905 \text { to } 1951 \\
\text { (excluding war years). }\end{array}$ & $\begin{array}{l}\text { Smyth, D. J. (1993), “Towards a theory of saving”, } \\
\text { In J. H. Gapinski (Ed.), The economics of saving } \\
\text { (pp. 67-69), New York: Springer Science + Business } \\
\text { Media. } \\
\text { https://books.google.fr/books?id=A23xCAAAQBA } \\
\text { J\&dq=marginal+propensity+to+consume+estimate } \\
\text { +permanent\&source=gbs_navlinks_s }\end{array}$ & 12 & [12] \\
\hline $\begin{array}{l}\text { United States. Aggregate data on disposable } \\
\text { income and savings between } 1959 \text { and } 1969 \\
\text { (most recent period available in the paper). } \\
\text { The central figure corresponds to the average } \\
\text { of reported estimates (Table 1-4). }\end{array}$ & $\begin{array}{l}\text { Leabo, D. A. (1971), "The declining marginal } \\
\text { propensity to save", Business Economics, Vol. 6, } \\
\text { No. 3, pp. 25-29. } \\
\text { http://www.jstor.org/stable/pdf/23480238.pdf?acce } \\
\text { ptTC=true }\end{array}$ & 12 & {$[8-21]$} \\
\hline $\begin{array}{l}\text { International. Annual data on personal } \\
\text { saving and personal disposable income for } 22 \\
\text { countries over the period 1953-1960 from the }\end{array}$ & $\begin{array}{l}\text { Friend, I. and P. Taubman (1966), "The aggregate } \\
\text { propensity to save: some concepts and their } \\
\text { application to international data", The Review of }\end{array}$ & 17.5 & {$[15-20]$} \\
\hline
\end{tabular}




\begin{tabular}{|c|c|c|c|}
\hline $\begin{array}{l}\text { yearbooks of National Account Statistics of } \\
\text { the United Nations Statistical Office. Under } \\
\text { the authors preferred methodology, the } \\
\text { estimate of the MPS out of a permanent shock } \\
\text { is in the neighbourhood of } 15 \% \text { to } 20 \% \text {. The } \\
\text { central figure corresponds to the average of } \\
\text { the two. }\end{array}$ & $\begin{array}{l}\text { Economics and Statistics, Vol. 48, No. 2, pp. 113- } \\
123 . \\
\text { http://www.jstor.org/stable/pdf/1924628.pdf }\end{array}$ & & \\
\hline $\begin{array}{l}\text { United States. Personal savings data from the } \\
\text { US Office of Business Economics and } \\
\text { financial assets data from the Security } \\
\text { Exchange Commission. The range and central } \\
\text { estimate of the MPS from normal income was } \\
\text { collected from Table } 1 .\end{array}$ & $\begin{array}{l}\text { Taubman, P. (1968), “A time series analysis of three } \\
\text { measures of the same conceptual series", The Review } \\
\text { of Economics and Statistics, Vol. 50, No. 1, pp. 125- } \\
129 . \\
\text { http://www.jstor.org/stable/pdf/1927065.pdf?accept } \\
\underline{\text { TC=true }}\end{array}$ & 13 & {$[7-20]$} \\
\hline $\begin{array}{l}\text { Canada. This paper extends the analysis in } \\
\text { Dynan et al. (2004) to Canada. The MPS } \\
\text { found ranges between } 6 \% \text { and } 30 \% \text {. }\end{array}$ & $\begin{array}{l}\text { Alan, S. and K. Atalay (2015), "Do the Rich Save } \\
\text { More? Evidence from Canada", Review of Income } \\
\text { and Wealth, Vol. 61, No. 4, pp. 739-758. } \\
\underline{\text { http://onlinelibrary.wiley.com/doi/10.1111/roiw.12 }} \\
\underline{\text { 131/abstract }}\end{array}$ & 18 & {$[6-30]$} \\
\hline $\begin{array}{l}\text { United States. Consumption and wealth data } \\
\text { from } 1955 \text { to } 1991 \text {. The MPS estimates were } \\
\text { collected from Table 2: the central value } \\
\text { corresponds to the whole sample period, while } \\
\text { the MPS range includes estimates for } \\
\text { alternative time periods. }\end{array}$ & $\begin{array}{l}\text { Stein, Sheldon H. and F. Song (1998), "The textbook } \\
\text { consumption function: a recent empirical } \\
\text { irregularity, a comment", The American Economist, } \\
\text { Vol. 42, No. 1, pp. 112-118. } \\
\text { http://www.jstor.org/stable/pdf/25604133.pdf?acce } \\
\text { ptTC=true }\end{array}$ & 19 & [19-34] \\
\hline $\begin{array}{l}\text { Germany. This paper uses a differences-in- } \\
\text { differences method to compare the saving } \\
\text { behaviour of natives and immigrants in } \\
\text { Germany, before and after a reform that eased } \\
\text { citizenship requirements. The MPS of natives } \\
\text { is between } 17.7 \% \text { and } 18.3 \% \text {, while the one of } \\
\text { immigrants is } 7 \text { to } 11 \text { percentage points } \\
\text { higher. }\end{array}$ & $\begin{array}{l}\text { Piracha, M. and Y. Zhu (2008), "Precautionary } \\
\text { Savings by Natives and Immigrants in Germany", } \\
\text { Department of Economics Discussions Papers, } \\
\text { KDPE 0821, University of Kent. } \\
\text { https://www.kent.ac.uk/economics/documents/resea } \\
\text { rch/papers/2008/0821.pdf }\end{array}$ & 18 & $\begin{array}{c}{[17.7-} \\
18.3]\end{array}$ \\
\hline $\begin{array}{l}\text { Theoretical model calibrated. Under most } \\
\text { simulated results, the MPS ranges between } \\
8 \% \text { and } 25 \% \text { and the average value is } 21 \% \\
\text { (Table 1). }\end{array}$ & $\begin{array}{l}\text { Carroll, C. D. (2009), "Precautionary saving and the } \\
\text { marginal propensity to consume out of permanent } \\
\text { income", NBER Working Paper, No. 8233. } \\
\text { http://www.nber.org/papers/w8233.pdf }\end{array}$ & 21 & {$[8-25]$} \\
\hline Average from all sources & - & 16.2 & {$[10.9-23]$} \\
\hline
\end{tabular}


Table A6.2. Ratio of the marginal propensity to save to the average saving rate

\begin{tabular}{|l|c|c|c|}
\hline \multicolumn{1}{|c|}{ Country } & $\begin{array}{c}\text { Average Saving } \\
\text { Rate (national } \\
\text { statistic } \\
\text { offices)(years in } \\
\text { parentheses) }\end{array}$ & $\begin{array}{c}\text { Marginal } \\
\text { propensity to } \\
\text { save (see table } \\
\text { A6.1 above) }\end{array}$ & Ratio \\
\hline Canada & $7.5(1981-2016)$ & 18 & 2.4 \\
\hline Germany & $11.9(1960-2016)$ & 18 & 1.5 \\
\hline United Kingdom & $8.4(1955-2016)$ & 18 & 2.1 \\
\hline United States & $8.3(1969-2016)$ & 14.3 & 1.7 \\
\hline Average & $\mathbf{9 . 0}$ & $\mathbf{1 7 . 1}$ & 1.9 \\
\hline
\end{tabular}

Source: Authors' calculations based on results from reported studies. 
Table 1. Data sources

\begin{tabular}{|c|c|c|c|c|c|c|c|c|}
\hline Datasets & Canada & France & Germany & Spain & UK & USA & Korea & Japan \\
\hline $\begin{array}{l}\text { Total wealth } \\
\text { shares }\end{array}$ & \multicolumn{6}{|c|}{ OECD Datasets: Wealth Distribution Database } & $\begin{array}{l}\text { Leipziger et } \\
\text { all (1992) }\end{array}$ & \begin{tabular}{|l|} 
National Survey of \\
Family Income and \\
Expenditure, 1994
\end{tabular} \\
\hline $\begin{array}{l}\text { Consumption } \\
\text { shares }\end{array}$ & $\begin{array}{l}\text { Canada } \\
\text { Survey of } \\
\text { Household } \\
\text { Spending } \\
2013\end{array}$ & \multicolumn{4}{|c|}{$\begin{array}{l}\text { Eurostat: Mean Consumption Expenditure by } \\
\text { Income Quintiles } 2010\end{array}$} & \begin{tabular}{|l|} 
USA \\
Consumer \\
Expenditure \\
Survey, 2013 \\
\end{tabular} & \begin{tabular}{|l|} 
Statistics \\
Korea: \\
income and \\
consumption \\
2014
\end{tabular} & \begin{tabular}{|l} 
Family Income and \\
Expenditure \\
Survey 2013, \\
Japan
\end{tabular} \\
\hline Income shares & \begin{tabular}{|l|} 
Canada \\
Market, total \\
and after-tax \\
income of \\
individuals \\
2011
\end{tabular} & \multicolumn{4}{|c|}{ Eurostat: Distribution of Income by Quantiles 2014} & \begin{tabular}{|l|} 
USA \\
Consumer \\
Expenditure \\
Survey, 2013 \\
\end{tabular} & \begin{tabular}{|l|} 
Statistics \\
Korea: \\
income and \\
consumption \\
2014
\end{tabular} & $\begin{array}{l}\text { Family Income and } \\
\text { Expenditure } \\
\text { Survey 2013, } \\
\text { Japan }\end{array}$ \\
\hline $\begin{array}{l}\text { Income share of } \\
\text { labour }\end{array}$ & \multicolumn{8}{|c|}{ Ameco's Adjusted wage share in selected OECD-Countries, 1990-2008 in Krämer (2011) } \\
\hline $\begin{array}{l}\text { Average saving } \\
\text { rates }\end{array}$ & $\begin{array}{l}\text { Statistics } \\
\text { Canada }\end{array}$ & $\begin{array}{l}\text { INSEE } \\
\text { France }\end{array}$ & \begin{tabular}{|l|} 
Deutsche \\
Bundesbank
\end{tabular} & Eurostat & $\begin{array}{l}\text { Office for } \\
\text { National } \\
\text { Statistics }\end{array}$ & \begin{tabular}{|l|} 
U.S. Bureau \\
of Economics \\
Analysis
\end{tabular} & $\begin{array}{l}\text { Statistics } \\
\text { Korea }\end{array}$ & $\begin{array}{l}\text { Statistics Bureau } \\
\text { of Japan }\end{array}$ \\
\hline $\begin{array}{l}\text { Marginal } \\
\text { propensity to save }\end{array}$ & \multicolumn{8}{|c|}{ Literature sources in Annex A1. } \\
\hline Mark-ups & \multicolumn{8}{|c|}{ Høj, J. et al (2007). } \\
\hline
\end{tabular}


Table 2. Excess mark-ups and price impact (all units in percentages)

\begin{tabular}{ccccc}
\hline Country & $\begin{array}{c}\text { Average mark-up } \\
\left(\boldsymbol{\mu}^{\mathrm{m}}\right)\end{array}$ & $\begin{array}{c}\text { Minimum mark- Excess mark-up } \\
\text { up }\left(\boldsymbol{\mu}^{\mathrm{c}}\right)\end{array}$ & $\begin{array}{c}\text { Impact of market } \\
\left(\boldsymbol{\mu}^{\mathrm{m}}-\boldsymbol{\mu}^{\mathrm{c}}\right)\end{array}$ & $\begin{array}{c}\text { power on prices } \\
(\boldsymbol{\alpha})\end{array}$ \\
\hline Canada & 17.7 & 10.1 & 7.6 & 8.4 \\
France & 19.2 & 10.2 & 9.0 & 10.0 \\
Germany & 20.9 & 10.3 & 10.6 & 11.8 \\
Japan & 15.5 & 9.9 & 5.6 & 6.2 \\
Korea & 20.5 & 10.0 & 10.5 & 11.7 \\
Spain & 20.0 & 10.4 & 9.6 & 10.7 \\
United Kingdom & 13.5 & 9.6 & 3.9 & 4.3 \\
United States & 16.7 & 11.0 & 5.7 & 6.4 \\
\hline Average & 18.0 & 10.2 & 7.8 & 8.7
\end{tabular}

Source: Authors' calculations, based on sector weights from STAN Database and sector-specific mark-ups calculated in Høj, J. et al. (2007). 
Table 3. Impact of market power on wealth shares (all units in percentages)

\begin{tabular}{|c|c|c|c|c|c|c|c|c|c|}
\hline \multicolumn{5}{|l|}{ Canada } & \multicolumn{5}{|l|}{ France } \\
\hline \multirow{2}{*}{ Percentile } & \multirow{2}{*}{$\begin{array}{c}\text { Current wealth } \\
\text { share }\end{array}$} & \multicolumn{3}{|c|}{ Wealth share absent market power } & \multirow{2}{*}{ Percentile } & \multirow{2}{*}{$\begin{array}{c}\text { Current wealth } \\
\text { share }\end{array}$} & \multicolumn{3}{|c|}{ Wealth share absent market power } \\
\hline & & $s^{\prime}=\bar{s}$ & $s^{\prime}=1.5 \bar{s}$ & $s^{\prime}=2 \bar{s}$ & & & $s^{\prime}=\bar{s}$ & $s^{\prime}=1.5 \bar{s}$ & $s^{\prime}=2 \vec{s}$ \\
\hline Bottom 20 & 0.41 & 0.89 & 1.34 & 2.20 & Bottom 20 & 0.33 & 1.53 & 2.57 & 4.30 \\
\hline $21-40$ & 4.08 & 4.75 & 5.39 & 6.59 & $21-40$ & 2.44 & 3.97 & 5.30 & 7.50 \\
\hline $41-60$ & 10.03 & 10.67 & 11.28 & 12.43 & $41-60$ & 10.87 & 11.74 & 12.50 & 13.76 \\
\hline $61-80$ & 19.75 & 20.18 & 20.58 & 21.35 & $61-80$ & 20.73 & 20.86 & 20.98 & 21.17 \\
\hline $81-90$ & 17.51 & 17.40 & 17.29 & 17.08 & $81-90$ & 17.15 & 16.69 & 16.28 & 15.62 \\
\hline $91-95$ & 13.40 & 13.09 & 12.79 & 12.24 & $91-95$ & 13.18 & 12.59 & 12.07 & 11.22 \\
\hline $96-99$ & 19.89 & 19.07 & 18.29 & 16.84 & $96-99$ & 18.04 & 16.94 & 15.98 & 14.40 \\
\hline Top 1 & 14.93 & 13.96 & 13.02 & 11.28 & Top 1 & 17.27 & 15.67 & 14.28 & 11.98 \\
\hline \multicolumn{5}{|l|}{ Germany } & \multicolumn{5}{|l|}{ Japan } \\
\hline \multirow{2}{*}{ Percentile } & \multirow{2}{*}{$\begin{array}{c}\text { Current wealth } \\
\text { share }\end{array}$} & \multicolumn{3}{|c|}{ Wealth share absent market power } & \multirow{2}{*}{ Percentile } & \multirow{2}{*}{$\begin{array}{c}\text { Current wealth } \\
\text { share }\end{array}$} & \multicolumn{3}{|c|}{ Wealth share absent market power } \\
\hline & & $s^{\prime}=\bar{s}$ & $s^{\prime}=1.5 \bar{s}$ & $s^{\prime}=2 \bar{s}$ & & & $s^{\prime}=\bar{s}$ & $s^{\prime}=1.5 \bar{s}$ & $s^{\prime}=2 \bar{s}$ \\
\hline Bottom 20 & -0.08 & 1.20 & 2.38 & 4.43 & Bottom 20 & 2.01 & 2.78 & 3.51 & 4.90 \\
\hline $21-40$ & 1.38 & 3.43 & 5.31 & 8.60 & $21-40$ & 6.61 & 7.35 & 8.06 & 9.40 \\
\hline $41-60$ & 6.27 & 8.19 & 9.94 & 13.02 & $41-60$ & 12.84 & 13.32 & 13.77 & 14.64 \\
\hline $61-80$ & 17.52 & 18.45 & 19.29 & 20.78 & $61-80$ & 21.66 & 21.80 & 21.93 & 22.17 \\
\hline $81-90$ & 17.01 & 16.62 & 16.26 & 15.63 & $81-90$ & 17.15 & 16.91 & 16.68 & 16.24 \\
\hline $91-95$ & 13.56 & 12.77 & 12.05 & 10.79 & $91-95$ & 16.94 & 15.96 & 15.01 & 13.23 \\
\hline $96-99$ & 21.07 & 19.09 & 17.29 & 14.12 & $96-99$ & 16.63 & 15.90 & 15.20 & 13.88 \\
\hline Top 1 & 23.28 & 20.23 & 17.45 & 12.57 & Top 1 & 6.15 & 5.99 & 5.84 & 5.54 \\
\hline \multicolumn{5}{|l|}{ Korea } & \multicolumn{5}{|l|}{ Spain } \\
\hline \multirow{2}{*}{ Percentile } & \multirow{2}{*}{$\begin{array}{l}\text { Current wealth } \\
\text { share }\end{array}$} & \multicolumn{3}{|c|}{ Wealth share absent market power } & \multirow{2}{*}{ Percentile } & Current wealth & Wea & e absent $\mathrm{m}$ & ower \\
\hline & & $s^{\prime}=\bar{s}$ & $s^{\prime}=1.5 \bar{s}$ & $s^{\prime}=2 \bar{s}$ & & share & $s^{\prime}=\bar{s}$ & $s^{\prime}=1.5 \bar{s}$ & $s^{\prime}=2 \bar{s}$ \\
\hline Bottom 20 & 1.80 & 2.62 & 3.33 & 4.50 & Bottom 20 & 1.69 & 2.36 & 2.99 & 4.16 \\
\hline $21-40$ & 5.60 & 6.87 & 7.96 & 9.78 & $21-40$ & 7.34 & 8.09 & 8.81 & 10.12 \\
\hline $41-60$ & 11.50 & 12.60 & 13.55 & 15.13 & $41-60$ & 12.82 & 13.52 & 14.18 & 15.39 \\
\hline $61-80$ & 21.00 & 21.47 & 21.88 & 22.56 & $61-80$ & 20.06 & 20.67 & 21.25 & 22.32 \\
\hline $81-90$ & 17.00 & 16.74 & 16.52 & 16.15 & $81-90$ & 15.66 & 15.70 & 15.73 & 15.80 \\
\hline $91-95$ & 12.20 & 11.48 & 10.85 & 9.81 & $91-95$ & 12.35 & 11.99 & 11.64 & 11.01 \\
\hline $96-99$ & 16.70 & 15.54 & 14.53 & 12.86 & $96-99$ & 15.52 & 14.73 & 13.98 & 12.59 \\
\hline Top 1 & 14.20 & 12.69 & 11.38 & 9.22 & Top 1 & 14.55 & 12.96 & 11.46 & 8.68 \\
\hline United Kin & gdom & & & & United Sta & tes & & & \\
\hline Percentile & Current wealth & Wea & e absent $\mathrm{m}$ & ower & Percentile & Current wealth & Wea & e absent $\mathrm{m}$ & ower \\
\hline Percentıle & share & $s^{\prime}=\bar{s}$ & $s^{\prime}=1.5 \bar{s}$ & $s^{\prime}=2 \bar{s}$ & Percentile & share & $s^{\prime}=\bar{s}$ & $s^{\prime}=1.5 \bar{s}$ & $s^{\prime}=2 \bar{s}$ \\
\hline Bottom 20 & 0.87 & 1.25 & 1.58 & 2.10 & Bottom 20 & -0.92 & -0.51 & -0.13 & 0.55 \\
\hline $21-40$ & 4.76 & 5.20 & 5.58 & 6.19 & $21-40$ & 0.90 & 1.65 & 2.35 & 3.63 \\
\hline $41-60$ & 11.76 & 12.05 & 12.31 & 12.71 & $41-60$ & 3.13 & 4.20 & 5.20 & 7.01 \\
\hline $61-80$ & 20.70 & 20.83 & 20.94 & 21.11 & $61-80$ & 9.14 & 10.42 & 11.62 & 13.78 \\
\hline $81-90$ & 16.61 & 16.52 & 16.45 & 16.33 & $81-90$ & 10.86 & 11.41 & 11.93 & 12.86 \\
\hline $91-95$ & 12.15 & 11.99 & 11.85 & 11.63 & $91-95$ & 12.08 & 12.04 & 12.01 & 11.96 \\
\hline $96-99$ & 16.39 & 16.03 & 15.72 & 15.22 & $96-99$ & 27.95 & 26.60 & 25.33 & 23.04 \\
\hline Top 1 & 16.75 & 16.12 & 15.58 & 14.71 & Top 1 & 36.85 & 34.18 & 31.69 & 27.18 \\
\hline
\end{tabular}

Source: Authors' calculations. 
Table 4. Impact of market power on the wealth of the richest $10 \%$ of households (all units in percentages)

\begin{tabular}{|c|c|c|c|c|c|c|c|}
\hline \multirow{2}{*}{ Country } & \multirow{2}{*}{$\begin{array}{l}\text { Current wealth } \\
\text { share of top } 10 \%\end{array}$} & \multicolumn{3}{|c|}{ Wealth share of top $10 \%$ without market power } & \multicolumn{3}{|c|}{ Rate of change in wealth (-) } \\
\hline & & $s^{\prime}=\bar{s}$ & $s^{\prime}=1.5 \bar{s}$ & $s^{\prime}=2 \bar{s}$ & $s^{\prime}=\bar{s}$ & $s^{\prime}=1.5 \bar{s}$ & $s^{\prime}=2 \bar{s}$ \\
\hline Canada & 48.2 & 46.1 & 44.1 & 40.4 & 4.4 & 8.5 & 16.3 \\
\hline France & 48.5 & 45.2 & 42.3 & 37.6 & 6.8 & 12.7 & 22.5 \\
\hline Germany & 57.9 & 52.1 & 46.8 & 37.5 & 10.0 & 19.2 & 35.3 \\
\hline Japan & 39.7 & 37.8 & 36.0 & 32.6 & 4.7 & 9.3 & 17.8 \\
\hline Korea & 43.1 & 39.7 & 36.8 & 31.9 & 7.9 & 14.7 & 26.0 \\
\hline Spain & 42.4 & 39.7 & 37.1 & 32.3 & 6.5 & 12.6 & 23.9 \\
\hline United Kingdom & 45.3 & 44.1 & 43.1 & 41.6 & 2.6 & 4.8 & 8.3 \\
\hline United States & 76.9 & 72.8 & 69.0 & 62.2 & 5.3 & 10.2 & 19.1 \\
\hline Average & 50.3 & 47.2 & 44.4 & 39.5 & 6.0 & 11.5 & 21.1 \\
\hline
\end{tabular}

Source: Authors' calculations; see Table 3. 
Table 5. Impact of market power on income shares (all units in percentages)

\begin{tabular}{|c|c|c|c|c|c|c|c|c|c|}
\hline \multicolumn{5}{|l|}{ Canada } & \multicolumn{5}{|l|}{ France } \\
\hline \multirow{2}{*}{ Percentile } & \multirow{2}{*}{$\begin{array}{c}\text { Current income } \\
\text { share }\end{array}$} & \multicolumn{3}{|c|}{ Income share absent market power } & \multirow{2}{*}{ Percentile } & \multirow{2}{*}{$\begin{array}{c}\text { Current income } \\
\text { share }\end{array}$} & \multicolumn{3}{|c|}{ Income share absent market power } \\
\hline & & $s^{\prime}=\bar{s}$ & $s^{\prime}=1.5 \bar{s}$ & $s^{\prime}=2 \bar{s}$ & & & $s^{\prime}=\bar{s}$ & $s^{\prime}=1.5 \bar{s}$ & $s^{\prime}=2 \bar{s}$ \\
\hline Bottom 20 & 4.39 & 4.87 & 5.01 & 5.28 & Bottom 20 & 9.00 & 10.20 & 10.50 & 10.98 \\
\hline $21-40$ & 9.68 & 10.35 & 10.56 & 10.94 & $21-40$ & 13.50 & 15.03 & 15.41 & 16.03 \\
\hline $41-60$ & 15.37 & 16.01 & 16.21 & 16.57 & $41-60$ & 17.20 & 18.08 & 18.29 & 18.65 \\
\hline $61-80$ & 23.31 & 23.74 & 23.87 & 24.11 & $61-80$ & 21.70 & 21.83 & 21.87 & 21.92 \\
\hline $81-90$ & 16.56 & 16.45 & 16.41 & 16.35 & $81-90$ & 13.80 & 13.34 & 13.22 & 13.03 \\
\hline $91-95$ & 10.80 & 10.49 & 10.39 & 10.22 & $91-95$ & 8.90 & 8.31 & 8.16 & 7.92 \\
\hline $96-99$ & 13.09 & 12.27 & 12.02 & 11.56 & $96-99$ & 10.10 & 9.00 & 8.73 & 8.28 \\
\hline Top 1 & 6.80 & 5.83 & 5.53 & 4.98 & Top 1 & 5.70 & 4.10 & 3.70 & 3.05 \\
\hline \multicolumn{5}{|l|}{ Germany } & \multicolumn{5}{|l|}{ Japan } \\
\hline \multirow{2}{*}{ Percentile } & \multirow{2}{*}{$\begin{array}{c}\text { Current income } \\
\text { share }\end{array}$} & \multicolumn{3}{|c|}{ Income share absent market power } & \multirow{2}{*}{ Percentile } & \multirow{2}{*}{$\begin{array}{c}\text { Current income } \\
\text { share }\end{array}$} & \multicolumn{3}{|c|}{ Income share absent market power } \\
\hline & & $s^{\prime}=\bar{s}$ & $s^{\prime}=1.5 \bar{s}$ & $s^{\prime}=2 \bar{s}$ & & & $s^{\prime}=\bar{s}$ & $s^{\prime}=1.5 \bar{s}$ & $s^{\prime}=2 \bar{s}$ \\
\hline Bottom 20 & 7.50 & 8.79 & 9.14 & 9.76 & Bottom 20 & 10.78 & 11.55 & 11.78 & 12.23 \\
\hline $21-40$ & 13.50 & 15.56 & 16.12 & 17.11 & $21-40$ & 15.09 & 15.83 & 16.06 & 16.49 \\
\hline $41-60$ & 17.60 & 19.52 & 20.05 & 20.97 & $41-60$ & 18.30 & 18.78 & 18.93 & 19.21 \\
\hline $61-80$ & 23.00 & 23.93 & 24.18 & 24.63 & $61-80$ & 23.21 & 23.34 & 23.38 & 23.46 \\
\hline $81-90$ & 14.70 & 14.31 & 14.20 & 14.01 & $81-90$ & 14.37 & 14.13 & 14.05 & 13.91 \\
\hline $91-95$ & 8.90 & 8.11 & 7.89 & 7.51 & $91-95$ & 5.66 & 4.68 & 4.37 & 3.80 \\
\hline $96-99$ & 9.40 & 7.42 & 6.88 & 5.93 & $96-99$ & 8.28 & 7.55 & 7.33 & 6.91 \\
\hline Top 1 & 5.30 & 2.25 & 1.42 & -0.05 & Top 1 & 4.30 & 4.14 & 4.09 & 4.00 \\
\hline \multicolumn{5}{|l|}{ Korea } & \multicolumn{5}{|l|}{ Spain } \\
\hline \multirow{2}{*}{ Percentile } & \multirow{2}{*}{$\begin{array}{c}\text { Current income } \\
\text { share }\end{array}$} & \multicolumn{3}{|c|}{ Income share absent market power } & \multirow{2}{*}{ Percentile } & Current income & Inco & re absent $\mathrm{m}$ & ower \\
\hline & & $s^{\prime}=\bar{s}$ & $s^{\prime}=1.5 \bar{s}$ & $s^{\prime}=2 \bar{s}$ & & share & $s^{\prime}=\bar{s}$ & $s^{\prime}=1.5 \bar{s}$ & $s^{\prime}=2 \bar{s}$ \\
\hline Bottom 20 & 6.79 & 7.61 & 7.81 & 8.14 & Bottom 20 & 6.00 & 6.67 & 6.87 & 7.23 \\
\hline $21-40$ & 13.33 & 14.59 & 14.90 & 15.41 & $21-40$ & 12.20 & 12.96 & 13.18 & 13.59 \\
\hline $41-60$ & 18.21 & 19.31 & 19.58 & 20.03 & $41-60$ & 17.30 & 18.00 & 18.20 & 18.58 \\
\hline $61-80$ & 23.88 & 24.35 & 24.47 & 24.66 & $61-80$ & 24.00 & 24.61 & 24.79 & 25.13 \\
\hline $81-90$ & 15.43 & 15.17 & 15.11 & 15.01 & $81-90$ & 15.90 & 15.94 & 15.95 & 15.97 \\
\hline $91-95$ & 7.78 & 7.06 & 6.88 & 6.59 & $91-95$ & 10.00 & 9.63 & 9.53 & 9.33 \\
\hline $96-99$ & 9.59 & 8.43 & 8.14 & 7.67 & $96-99$ & 10.40 & 9.60 & 9.37 & 8.93 \\
\hline Top 1 & 4.99 & 3.48 & 3.11 & 2.50 & Top 1 & 4.30 & 2.71 & 2.23 & 1.36 \\
\hline United Kin & gdom & & & & United Sta & tes & & & \\
\hline Percentile & Current income & Incol & e absent $\mathrm{m}$ & ower & Percentile & Current income & Inco & re absent $\mathrm{m}$ & ower \\
\hline Percentile & share & $s^{\prime}=\bar{s}$ & $s^{\prime}=1.5 \bar{s}$ & $s^{\prime}=2 \bar{s}$ & Percentile & share & $s^{\prime}=\bar{s}$ & $s^{\prime}=1.5 \bar{s}$ & $s^{\prime}=2 \bar{s}$ \\
\hline Bottom 20 & 7.80 & 8.18 & 8.27 & 8.42 & Bottom 20 & 3.69 & 4.09 & 4.21 & 4.42 \\
\hline $21-40$ & 12.80 & 13.25 & 13.35 & 13.52 & $21-40$ & 9.45 & 10.20 & 10.42 & 10.81 \\
\hline $41-60$ & 17.10 & 17.40 & 17.47 & 17.58 & $41-60$ & 15.31 & 16.38 & 16.69 & 17.25 \\
\hline $61-80$ & 23.00 & 23.13 & 23.16 & 23.21 & $61-80$ & 23.69 & 24.97 & 25.34 & 26.01 \\
\hline $81-90$ & 15.00 & 14.91 & 14.89 & 14.86 & $81-90$ & 17.15 & 17.70 & 17.86 & 18.15 \\
\hline $91-95$ & 9.20 & 9.04 & 9.00 & 8.94 & $91-95$ & 11.70 & 11.67 & 11.66 & 11.64 \\
\hline $96-99$ & 9.80 & 9.43 & 9.35 & 9.21 & $96-99$ & 12.53 & 11.17 & 10.78 & 10.07 \\
\hline Top 1 & 5.30 & 4.67 & 4.52 & 4.28 & Top 1 & 6.51 & 3.85 & 3.08 & 1.68 \\
\hline
\end{tabular}

Source: Authors' calculations. 
Table 6. Impact of market power on the income of the poorest $20 \%$ of households (all units in percentages)

\begin{tabular}{|c|c|c|c|c|c|c|c|}
\hline \multirow{2}{*}{ Country } & \multirow{2}{*}{$\begin{array}{c}\text { Current income } \\
\text { share of bottom } 20 \%\end{array}$} & \multicolumn{3}{|c|}{ Income share of bottom $20 \%$ without market power } & \multicolumn{3}{|c|}{ Rate of change in income } \\
\hline & & $s^{\prime}=\bar{s}$ & $s^{\prime}=1.5 \bar{s}$ & $s^{\prime}=2 \bar{s}$ & $s^{\prime}=\bar{s}$ & $s^{\prime}=1.5 \bar{s}$ & $s^{\prime}=2 \bar{s}$ \\
\hline Canada & 4.4 & 4.9 & 5.0 & 5.3 & 10.9 & 14.2 & 20.3 \\
\hline France & 9.0 & 10.2 & 10.5 & 11.0 & 13.3 & 16.6 & 22.1 \\
\hline Germany & 7.5 & 8.8 & 9.1 & 9.8 & 17.1 & 21.8 & 30.1 \\
\hline Japan & 10.8 & 11.5 & 11.8 & 12.2 & 7.1 & 9.3 & 13.4 \\
\hline Korea & 6.8 & 7.6 & 7.8 & 8.1 & 12.0 & 15.0 & 19.9 \\
\hline Spain & 6.0 & 6.7 & 6.9 & 7.2 & 11.2 & 14.5 & 20.6 \\
\hline United Kingdom & 7.8 & 8.2 & 8.3 & 8.4 & 4.9 & 6.1 & 7.9 \\
\hline United States & 3.7 & 4.1 & 4.2 & 4.4 & 11.0 & 14.1 & 19.9 \\
\hline Average & 7.0 & 7.7 & 7.9 & 8.3 & 10.9 & 14.0 & 19.3 \\
\hline
\end{tabular}

Source: Authors' calculations; see Table 5. 